\title{
Role of micronutrients in the periconceptional period
}

\author{
I. Cetin ${ }^{1,2,3}$, C. Berti 1,2, and S. Calabrese ${ }^{1,2}$
}

'Unit of Obstetrics and Gynecology, Department of Clinical Sciences, Hospital 'L. Sacco', University of Milan, Via G. B. Grassi, 74, 20157 Milano, Italy ${ }^{2}$ Center for Fetal Research Giorgio Pardi, University of Milan, Milan, Italy

${ }^{3}$ Correspondence address. Tel: +39-02-50319804; Fax: +39-02-50319806; E-mail: irene.cetin@unimi.it

\section{TABLE OF CONTENTS}

- Introduction

- Methods

- Role of specific dietary micronutrients
Antioxidants
Folate
Vitamin $\mathrm{B}_{12}$ or cobalamin
Vitamin $B_{6}$
Vitamin A
Iron
Zinc
Copper

- Critical stages and mechanisms potentially affected by nutrition in the periconceptional period

Embryogenesis

Implantation and placentation

Diabetes

Reactive oxygen species

Pre-eclampsia and IUGR

Influence of the preconceptional maternal diet and health status

- Effects of periconceptional micronutrients on pregnancy outcomes

The preconceptional period

Fertility

Conception and implantation

Placentation

Embryogenesis

- Conclusions

BACKGROUND: Micronutrient deficiencies have been associated with significantly high reproductive risks, ranging from infertility to fetal structural defects and long-term diseases. In this review we focus on the reproductive risks related to some micronutrients during the periconceptional period, a critical step in determining fetal development and health due to the potential onset of several disorders.

METHODs: Embase Medline and PubMed databases, Google-indexed scientific literature and periodics from on-line University of Milan Bibliotecary Service were searched to identify relevant publications. In vivo human studies were mainly searched for, but when needed animal studies as well as in vitro and cell culture experiments were also considered.

RESULTS: Fertility, conception, implantation, fetal organogenesis and placentation are the critical stages potentially affected by nutrition during the periconceptional period. Reactive oxygen species (ROS) and total homocysteine (tHcy) plasma levels are factors involved in the respective mechanisms. The preconceptional period is particularly important since it affects both fertility and the early stages of gestation. Micronutrients' dietary intake and maternal status affect the different phases of the onset and development of pregnancy as well as of the conceptus. 
CONCLUSION: Although human studies are scarce, and conclusive evidence is provided solely for periconceptional folate and prevention of neural tube defects (NTDs), the overall data indicate that micronutrients may affects fertility, embryogenesis and placentation, and the prophylactic use of some micronutrients may be useful in preventing several adverse pregnancy outcomes. Efforts to increase awareness of a healthy diet should be strengthened not only throughout pregnancy but also before. However, further researches in humans are necessary to optimise periconceptional micronutrient requirements.

Key words: periconceptional period / micronutrients / ROS / preconception nutrition / pregnancy outcomes

\section{Introduction}

Diet is recognized as one of the major environmental factors influencing the development of embryo and fetus, as well as maternal health (Keen et al., 2003). Particularly, micronutrient deficiencies have been associated with significantly high reproductive risks, ranging from infertility to fetal structural defects and long-term diseases (McArdle and Ashworth, 1999; Ashworth and Antipatis, 200I; Black, 200I; Andersen et al., 2006). There is evidence that indicates a role for micronutrients supplementation in preventing some pregnancy disorders (Ladipo, 2000; Bendich, 200I; Díaz et al., 2003). Among these, increasing calcium and magnesium intake can reduce the risk of pregnancy-induced hypertensive disorders; ensuring adequate intake of iron, zinc, iodine, calcium and folic acid during pregnancy can improve pregnancy outcomes; increasing the intake of folic acid before pregnancy can reduce birth defects; increasing folic acid and vitamin $B_{12}$ may reduce megaloblastic anaemia in mothers; providing zinc supplements during pregnancy can improve birthweight and reduce prematurity. Moreover, since micronutrients such as vitamin $A$, iron and zinc are also involved in the function of the immune system, their deficiency can lead to potentially harmful infections, and enhancing vitamin $A$ intake may reduce maternal mortality (West et al., 1999). Furthermore, improved maternal intake of many nutrients directly enhances the quality of breast milk (Picciano, 2003; Allen, 2005). However, the biological mechanisms responsible for these association are not completely clear.

Since pregnancy is characterized by different stages that represent a continuum, the timing of a nutritional insult impacts differently both on the overall outcome of pregnancy and on the nature of adult diseases by programming the post-natal pathophysiology, and having the potential to affect cell numbers or differentiation in the developing embryo (Newnham et al., 2002; Fleming et al., 2004; Rhind, 2004; Buckley et al., 2005; De Boo and Harding, 2006). Each stage in embryonic and fetal development is indeed strongly influenced by maternal nutrients and hormones (Ashworth and Antipatis, 200I; Sacks, 2004; Gluckman et al., 2008), and the placental-maternal-fetal somatotropic axes are fundamental in modulating this interaction (Gluckman and Pinal, 2002). As Bloomfield et al. (2004) demonstrated, periconceptional undernutrition in sheep from 60 day before to 30 day after mating alters the development of the fetal hypothalamic-pituitaryadrenal axes (HPAA) inducing accelerated maturation many months later, suggesting that events around the time of conception strongly affect fetal development in late gestation. The authors found significantly higher baseline cortisol levels and a significant positive association between plasma cortisol and adrenocorticotropic hormone concentration in fetuses by undernourished ewes compared with controls. In addition, Edwards and McMillen (2002) demonstrated that the detrimental effect on fetal HPAA of the maternal nutrient-restriction before and in the first week of gestation was not reversed by provision of a maintenance diet from the second week of pregnancy. Similarly, nutrient restriction of ewes, during perimplantation embryonic development, programs long-term cardiovascular dysfunction in adult offspring (Gardner et al., 2004). Interestingly, a maternal low-protein diet (LPD) in the first days of dams' pregnancy reduced cell number in both the inner cell mass and the mid/late blastocyst, and reduced insulin and essential amino acid levels in maternal serum, suggesting that long-term programming of post-natal growth and physiology (i.e. metabolic stress) may be induced irreversibly during the preimplantation period by maternal protein undernutrition through restriction of early embryonic proliferation (Kwong et al., 2000). Similarly, mouse embryo transfer experiments revealed a correlation between maternal preimplantation LPD and offspring's increased weight from birth, hypertension and abnormal anxiety-related behavior, indicating that increases in perinatal weight due to a maternal preimplantation LPD was induced within blastocysts, with the visceral yolk sac endoderm as a proposed mediator (Watkins et al., 2008).

Moreover, in human pregnancies studies in the offspring of women exposed to the Dutch Winter Famine showed that the nutrient environment in the first trimester of pregnancy was linked to increased prevalence of coronary heart disease, raised lipids and obesity (Ravelli et al., 1999; Roseboom et al., 2000, 200 I), whereas famine occurring during late gestation led to decreased glucose tolerance in adult life (Ravelli et al., 1998).

In particular, the periconceptional period is critical in determining fetal development and health. The onset of several malformations and pregnancy related disorders (i.e. congenital abnormalities, fetal loss, miscarriage, insufficient fetal growth, premature birth and preeclampsia) may indeed occur during this period (Steegers, 2005).

The present review aims to summarize the recent evidence about the reproductive risk factors related to micronutrients during the periconceptional period. Human in vivo studies were evaluated. The majority of these are observational and retrospective, and deal with energy and macronutrient intake. Data on the specific relationship between individual micronutrients and reproductive outcomes are often scarce, inconsistent or contradictory (Osrin et al., 2000; Shah and Sachdev, 2004). Therefore, animal, in vitro and cell culture studies were also considered to investigate the effects of micronutrients during the different phases of the onset and development of pregnancy and development of the conceptus.

\section{Methods}

Embase Medline and PubMed databases (all publication years), Googleindexed scientific literature as well as periodics from on-line University 
of Milan Bibliotecary Service were searched for all relevant articles written in English. Search terms included micronutrient intake, micronutrient supplements, micronutrient deficiency, periconceptional period, preconceptional period, food intake, diet, embryogenesis, placentation, fetus outcomes, maternal nutrition status, pregnancy outcomes, oxidative stress (OS) and fertility. Human, animal, in vitro and cell culture experiments were considered. Abstracts were critically evaluated to identify relevant articles focusing on periconceptional critical stages potentially affected by nutrition and effects of micronutrients' intake and maternal status during the different phases of the onset and development of pregnancy and conceptus. The reference lists of articles included in this review were examined for additional potential articles and books were also considered.

\section{Role of specific dietary micronutrients}

Malnutrition is the state produced by an inadequate intake of a good quality diet. This can mean intake of too few macronutrients, i.e. undernutrition (protein-energy malnutrition and/or vitamin and mineral deficiency), or of too many macronutrients, i.e. overnutrition (obesity), or excessive amounts of inappropriate substances (alcoholism). Interestingly, vitamin and mineral deficiency may occur in both undernutrition (mainly an issue in developing and transitional countries) and overnutrition (Young et al., 2004). For example, the globalized high-energy and low-nutrient density Western dietary patterns and trends, typified by snacking, breakfast skipping, fast foods, soft drinks and convenience foods, are nutritionally unbalanced, and intake of micronutrients in general fails to meet recommended daily allowance (RDA) values (Nicklas et al., 200I; Paeratakul et al., 2003; Drewnowski and Spencer, 2004; Cordain et al., 2005).

For this reason, micronutrient malnutrition represents an important topic of public health worldwide, mainly in vulnerable population groups such as infants, elderly, pregnant and lactating women. There is sound evidence that adequate intake of micronutrients can prevent many serious birth defects, reduce the risk of premature and low birthweight (LBW) infants, and support maternal health. Micronutrients seem to affect pregnancy outcomes through alterations in maternal and fetal metabolism due to their role/involvement in enzymes, signal transduction and transcription pathways and OS (McArdle and Ashworth, 1999). Here, we deal with micronutrients for which there is sufficient information and major public health concern; Table I shows their main functions.

\section{Antioxidants}

Complex antioxidant defenses are distributed within various cellular compartments and in the external milieu; plasma contains a wide range of substances with antioxidant properties.

Antioxidants are necessary for homeostasis; an imbalance in the equilibrium of antioxidants and pro-oxidants can result in OS damage, a key element in the pathogenesis of several diseases (Agarwal et al., 2008), via effects on redox status and/or redoxsensitive signaling pathways and gene expression (reviewed by Ruder et al., 2008). By both direct and indirect contributions, antioxidants enhance many aspects of the immune response (Bendich, 200I; Arrigoni and De Tullio, 2002) and limit pathological aspects of the cytokine-mediated response.
Antioxidants are present in both enzymatic (i.e. superoxide dismutase (SOD), catalase, glutathione (GSH) peroxidase, and GSH reductase) and non-enzymatic (i.e. vitamin $\mathrm{C}$, vitamin $\mathrm{E}$, selenium, zinc, taurine, hypotaurine, GSH, $\beta$-carotene and carotene) forms (Agarwal et al., 2008). Many antioxidants are obtained from the diet, such as vitamin $E$ and other tocopherols, vitamin $C, \beta$-carotene, whereas proteins and peptides, such as glutathione, ceruloplasmin and metallothionein, are synthesized endogenously (Grimble, 1998). Vitamin $\mathrm{E}$ is a chain-breaking antioxidant that prevents the propagation of free radical damage in biologic membranes, thus defending polyunsatured fatty acid (PUFA) from auto-oxidation (Traber, 2006). Vitamin $C$ or L-ascorbic acid, present mainly in vegetables and fruit, exhibits a protective effect against free-radical-induced oxidative damage by acting as a reducing agent (Levine et al., 2006). It is also important in the synthesis of collagen, carnitine, catecholamines. Other watersoluble vitamins, such as vitamin $B_{12}$, folic acid, vitamin $B_{6}$, riboflavin, are crucial for oxidative defense. Carotenoids and polyphenols are potent antioxidants. Other micronutrients such as magnesium, copper, zinc, manganese and selenium are involved in the antioxidant defense as cofactors of enzymes (i.e. zinc in metallothionein, copper in ceruloplasmin, copper-selenium-zinc in SOD, selenium in GSH peroxidase) (Fang et al., 2002).

\section{Folate}

Folate is widely distributed in foods (green-leafy vegetables, fruits, liver, bread etc.). An inadequate dietary folate intake results in a reduction of DNA biosynthesis and thereby of cell division, leading to anemia, leucopenia and thrombocytopenia etc. (FAO/WHO Report, 2004a). A decrease in the methylation cycle results in elevation of plasma total homocysteine (tHcy), or hyperhomocysteinemia (HHCY). HHCY is implicated in the etiology of several diseases such as arterial and/or venous thrombosis, vascular dementia by demyelization, and certain neuropathies, such as sub-acute combined degeneration of the spinal cord and peripheral nerves. In a meta-analysis of randomized trials it was demonstrated that daily supplementation with both $0.5-5 \mathrm{mg}$ folic acid and about $0.5 \mathrm{mg}$ vitamin $\mathrm{B}_{12}$ would be expected to reduce blood homocysteine concentrations by about a quarter to a third (Homocysteine Lowering Trialists' Collaboration, 1998). Moreover, as an effective scavenger of oxidizing free radicals, folic acid acts as antioxidant and can protect bio-constituents such as cellular membranes or DNA from free radical damage (Joshi et al., 200I).

\section{Vitamin $B_{12}$ or cobalamin}

Bacteria and algae synthesize vitamin $B_{12}$, and it enters the human food chain through incorporation into food of animal origin such as liver, milk, meat, oocytes (FAO/WHO Report, 2004b). Low vitamin $\mathrm{B}_{12}$ levels are related to $\mathrm{HHCY}$ and high methylmalonic acid. Anaemia, myelopathy and neuropathy are the main clinical manifestations of vitamin $B_{12}$ deficiency (Charmel, 2006). Intriguingly, the Pune Maternal Nutrition Study showed that at 6 years old, children born to mothers with low maternal vitamin $B_{12}$ status at 18 weeks of gestation and high folate status at 28 weeks were the most insulin resistant (Yajnik et al., 2008). Moreover, higher maternal erythrocyte folate concentrations at 28 weeks were associated with higher fat mass and per cent body fat in the offspring. The authors speculated 
Table I Main functions of micronutrients involved in the periconceptional period

\begin{tabular}{|c|c|c|}
\hline Micronutrient & Function & References \\
\hline Folate & $\begin{array}{l}\text { Involvement in the DNA replication (cell cycle); methylation cycle (amino acids } \\
\text { cysteine and methionine cycle) }\end{array}$ & $\begin{array}{l}\text { FAO/WHO Report (2004a), Scholl and Johnson } \\
\text { (2000) }\end{array}$ \\
\hline Vitamin $B_{12}$ & Conversion of homocysteine to methionine as cofactor of the methionine synthase & Ryan-Harshman and Aldoori (2008) \\
\hline Vitamin $B_{6}$ & $\begin{array}{l}\text { Metabolism of amino acids, lipids, one-carbon units and glycogen as co-enzyme; } \\
\text { pathways of gluconeogenesis, heme and neurotransmitter biosynthesis }\end{array}$ & Mackey et al. (2006) \\
\hline Vitamin A & Growth and differentiation of a number of cells and tissues & Ross (2006) \\
\hline Antioxidants & Defence systems against free radical species & Fang et al. (2002) \\
\hline Iron & $\begin{array}{l}\text { Haematopoiesis; nucleic acid metabolism; carrier of oxygen to the tissues by red } \\
\text { blood cell haemoglobin; transport medium for electrons within cells; integrated part } \\
\text { of important enzyme systems }\end{array}$ & $\begin{array}{l}\text { Cook et al. (1992); Beard (2003), FAO/WHO } \\
\text { Report (2004c), Wood and Ronnenberg (2006) }\end{array}$ \\
\hline Zinc & $\begin{array}{l}\text { Structural, regulatory and catalytic functions as cofactor for numerous } \\
\text { metalloenzymes }\end{array}$ & McCall et al. (2000), Hambidge (2000) \\
\hline Copper & $\begin{array}{l}\text { Neurotransmission, neuroropeptide maturation, oxidative phosphorylation, defence } \\
\text { from free radical damage as cofactor for numerous cuproenzymes and } \\
\text { copper-binding proteins }\end{array}$ & Turnlund (2006) \\
\hline
\end{tabular}

that vitamin $B_{12}$ deficiency prevents the generation of methionine from homocysteine by trapping folate as 5-methyltetrahydrofolate, and subsequently reduces protein synthesis and lean tissue deposition. Moreover, the increased lipogenesis might be caused by the inhibition of $\beta$-oxidation, owing to elevated concentrations of methylmalonicco-enzyme A. In fact, it can be hypothesized that imbalances of adequate folate methyl donor and poor vitamin $B_{12}$ cofactor lead to further depletion of mitochondrial cobalamin stores, thereby to dysfunction of other $B_{12}$-dependent reactions (Rosemberg, 2008). On the whole, these results postulate that the defects in the one-carbon metabolism plays a crucial role in intrauterine programming of adult diseases.

\section{Vitamin $\mathbf{B}_{6}$}

Foods of animal origin are rich in vitamin $\mathrm{B}_{6}$; wholegrains and many vegetables are also good sources. Deficiencies of vitamin $B_{6}$ may lead to $\mathrm{HHCY}$ (Mackey et al., 2006). Moreover, low plasma levels of vitamin $B_{6}$ are an independent risk factor for thrombosis (Saibeni et al., 2003).

\section{Vitamin A}

Vitamin A can be obtained from food either as pre-formed vitamin A, in the form of retinol or retinyl-esters which come from animal sources, or as provitamin A form from plants, i.e. provitamin $A$-carotenoids such as $\beta$-carotene. The highest concentration of vitamin $A$ is found in liver and fish liver oil. Yellow and green leafy vegetables provide provitamin A-carotenoids (Ross, 2006). Retinol is its endogenous metabolite and retinoic acid (RA), a vitamin A derivative, is a morphogenetically active compound. Vitamin A plays a key role in vision and ocular retinoid metabolism as well as in cellular differentiation (related to embryonic development and immunity). Carotenoids exert antioxidant properties. Vitamin A deficiency is linked to xerophthalmia and Vitamin A-deficiency anemia whereas hypervitaminosis seems to be involved in teratogenesis, liver abnormalies and bone mineral loss. Interestingly, it has been observed that in rodents the control of neural patterning and differentiation are disrupted when RA concentrations are lowered, whereas inappropriately high concentrations of RA result in abnormal development of cerebellum and hindbrain nuclei. Thereby, it has been supposed that even the adult brain may be susceptible to an imbalance of RA, particularly the hippocampus (McCaffery et al., 2003).

\section{Iron}

Nutritional sources of iron are meat, poultry, fish, cereals, bread and green vegetables (FAO/WHO Report, 2004c). Worldwide, iron deficiency represents the most common nutritional deficit (Scholl, 2005), that can exist with or without anemia. Although iron deficiency is a common cause of anemia, anemia may also result from other causes (i.e. deficiencies of folate, vitamin $B_{12}$ and vitamin $B_{6}$ ). Studies in both humans and animals have shown that iron-deficient anemia in early life is linked to altered behavioral and neural development, and is suggested to result in irreversible effects on neurochemistry and neurobiology (reviewed by Beard, 2003, 2007). This may be explained by considering alterations in morphology, neurochemistry and biogenetics within the central nervous system. In fact, data on human infants are consistent with altered myelination of white matter, changes in monoamine metabolism in striatum and functioning of the hippocampus (Beard, 2008).

\section{Zinc}

Zinc is abundantly present in meat, seafood, pulses, legumes and whole-grain cereals (FAO/WHO Report, 2004d; King and Cousins, 2006). Zinc has antioxidant properties, by counteracting oxidation through binding sulphydryl groups in proteins and by occupying binding sites for iron and copper in lipids, proteins and DNA (Zago and Oteiza, 200I). Evidence has been found for oxidative damage in zinc-deficient rats and mice (Oteiza et al., 1995), although zinc salts have been shown to protect against oxidative damage and glutathione depletion in mice (Bagchi et al., 1998). Moreover, zinc is present in the brain, bound to proteins, and it is important for its structure and function (Bhatnagar and Taneja, 200I). 


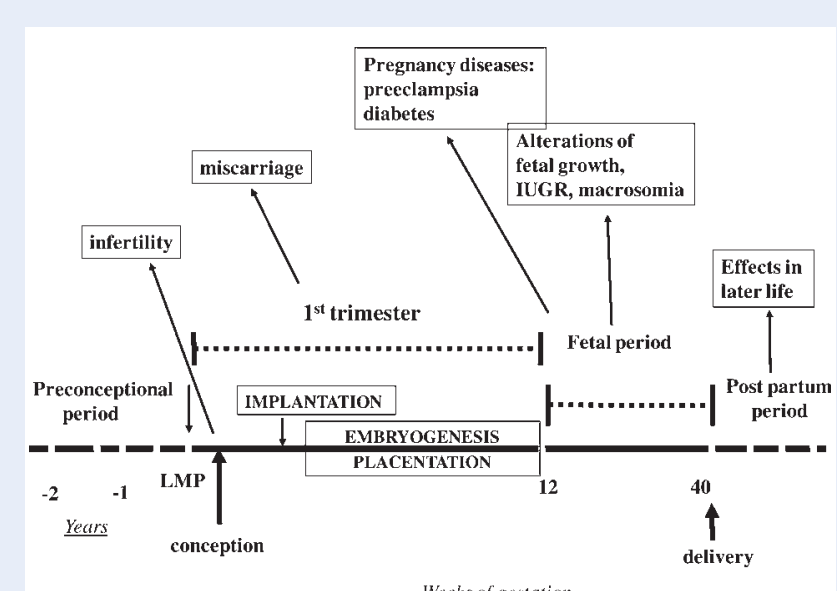

Figure I Different pregnancy stages that represent a continuum, from the preconceptional to the post-partum period.

Several and specific malformations and pregnancy related disorders may originate during each phase. Preconception, conception, implantation, placentation and embryo- or organogenesis are stages of the periconceptional period, which represents a critical step in determining fetus development. From the nutritional point of view, firstly preconceptional nutrition affects the overall health of childbearing-age women, thereby their reproductive potential. Subsequently, periconceptional maternal nutrition influences both the onset and the early stages of pregnancy, affecting both maternal health and conceptus development throughout the entire pregnancy. LMP: last menstrual period.

\section{Copper}

The richest dietary sources of copper include shellfish, nuts, seeds, legumes, grains' bran and germ, liver and organ meats. Copper exhibits several biological roles being involved in connective tissues formation, iron metabolism, cardiac function, immune function (Turnlund, 2006) and central nervous system development (Prohaska, 2000; Gybina and Prohaska, 2003). Interestingly, new insights are emerging into the role of iron and copper in neurocognitive and neurobehavioral development during the last two thirds of gestation, and in long-term consequences of their perinatal deficiency (Beard et al., 2003; Penland and Prohaska, 2004; Gybina and Prohaska, 2006; Beard, 2008). Balances between copper and iron are recognized to assure the proper brain development, as iron-deficiency results in hypomyelination (Prohaska and Gybina, 2005) to suggest that iron accumulation in rat brain during perinatal growth depends on adequate copper nutrition of dams.

\section{Critical stages and mechanisms potentially affected by nutrition in the periconceptional period}

The periconceptional period consists of preconception, conception, implantation, placentation and embryo- or organogenesis stages (Fig. I), and specific cellular events that occur during the distinct stages of embryogenesis (Hirschi and Keen, 2000). Besides genetics, each of these steps may be affected by maternal nutrition and, specifically, by micronutrient imbalances (Finnell et al., 2004; Allen, 2005). In particular, these may interfere with fetal organogenesis (embryogenesis) as well as with placentation.

\section{Embryogenesis}

The association between maternal folate status and fetal neural tube defects (NTDs) is well recognized, as demonstrated by several interventional trials and observational studies (reviewed by de Bree et al., 1997; Pitkin, 2007). Neural tube develops into the spine and NTDs occur when the brain and skull and/or the spinal cord and the protective spinal column do not develop properly within the first 4 weeks after conception. Folate functions as a co-enzyme in single-carbon transfers in the metabolism of aminoacids and nucleic acids. Moreover, folate is the substrate donor in the remethylation of homocysteine into methionine, catalyzed by methionine synthase and 5, 10-methylenetetrahydrofolatereductase (MTHFR). Altered homocysteine metabolism leading to HHCY has been proposed as the mechanism involved in NTDs given that higher tHcy levels were found in plasma or amniotic fluid of NTD infants and their mothers with respect to non-NTD individuals (Locksmith and Duff, 1998; Tamura and Picciano, 2006). Moreover, HHCY depends on inherited and acquired conditions (genetic polymorphisms of MTHFR 677 $\mathrm{C} \rightarrow \mathrm{T}$ and $1298 \mathrm{~A} \rightarrow \mathrm{C}$ ); methionine synthase (MTR) $2756 \mathrm{C} \rightarrow \mathrm{G}$; methionine synthase reductase (MTRR) $66 \mathrm{~A} \rightarrow \mathrm{G}$ ) (Guéant et al., 2003 ) and folate and/or vitamin $B_{6} / B_{12}$ deficiencies due to deregulation of their normal metabolism and/or low dietary intake (Steen et al., 1998).

\section{Implantation and placentation}

The process of implantation and placentation may also be affected by maternal nutrition. Placental function is critical for nourishing the fetus throughout pregnancy (Cross and Mickelson, 2006; Jansson and Powell, 2006; Pafilis et al., 2007). Specifically, the placenta forms a highly branched villous structure thus providing nutrients and oxygen to the fetus (Cetin et al., 2005) to assure appropriate fetal growth (Sparks et al., 1998). In particular, intrauterine growth restriction (IUGR) is associated with a range of alterations in placental transport functions, whereas accelerated fetal growth, in association with maternal diabetes, is characterized by increased activity of placental systems (Sacks, 2004; Cetin and Alvino, 2009). Nutrition may play a role in altering the development of the placenta. In fact, despite an initially normal growth trajectory, fetuses may have impaired growth in the second part of gestation subsequent to nutrient deprivation occurring early in gestation. Early in pregnancy the muscular maternal spiral arteries are transformed to fibrinoid lined vessels, and after further invasion by endovascular cytotrophoblasts, these vessels bath the chorionic villi in maternal blood bearing oxygen and nutrients for fetal development. Defects in this process have been reported in pregnancies complicated by IUGR (Sibley et al., 2005; Cetin and Alvino, 2009). Proposed mechanisms include lowered number and surface area of arterioles of tertiary villi, secondary vascular obliteration (Gagnon, 2003), increased susceptibility of trophoblasts to apoptosis by inflammatory cytokines or oxygen reduction (Crocker et al., 2003). Also, impaired release of the vasoactive agents nitric oxide (NO) and carbon monoxide by the invasive trophoblast cells seems to be responsible for the reduction in spiral artery transformation (Lyall, 2003). 


\section{Diabetes}

Blastocyst development and subsequent implantation are affected by high concentrations of D-glucose in diabetic mothers in a mouse model (Leunda-Casi et al., 200I, 2002). This has also been demonstrated in culturing rat embryos, as OS occurs in diabetes (Cedeberg et al., 200 I; Ornoy, 2007). Diabetes is associated with an imbalance between pro-oxidant and antioxidant defenses in favor of pro-oxidants, resulting in oxidative structural and functional modifications of biomolecules. These modifications may result in secondary trophoblast dysfunction (Jauniaux et al., 2006). Scavenging of free radicals is achieved through enzymatic and non-enzymatic reactions.

\section{Reactive oxygen species}

Reactive oxygen species (ROS), reactive nitrogen species and reactive chlorine species are produced in humans and animals under physiological and pathological conditions (reviewed by Fang et al. 2002). Free radicals play a key role in the origin of life and biological evolution, such as signal transduction and gene transcription, regulating platelet aggregation, leukocyte adhesion and angionesis, mediation of the immune response. As oxidants and inhibitors of iron-sulfur center enzymes, ROS cause oxidation of biomolecules such as DNA, lipids, proteins, leading to cell injury and death (cytotoxic effect). Furthermore, ROS are involved in female reproduction, that is physiological processes such as folliculogenesis, oocyte maturation, ovulation, corpus luteum formation, endometrial cycle, luteolysis, implantation, embryogenesis and pregnancy (reviewed by Taylor, 200I, Agarwal et al., 2005, 2008). As demonstrated in embryo culture systems and in pregnant animals with induced diabetes, ROS are suggested to be involved in diabetic teratogenesis and to contribute to the prostaglandin imbalance, resulting from myoinositol and arachidonic pathways, linking together potentially teratogenic mechanisms (Akazawa, 2005). In vitro, high glucose concentration impaired rat preimplantation embryo development or induced degeneration of the embryos due to apoptosis of blastocysts (Kos and Vogel, 2005) by suppression of insulin and glucokinase expression, decreased mitochondrial function, increased ROS formation and accelerated apoptosis, as well as to activation of common stress signaling pathways, which could affect proliferative, metabolic and neuroendocrine axes during later development (Evans et al., 2002). Thus, imbalance in homeostatic control of ROS exposure causes $O S$, which can affect fertilization and induce apoptosis, resulting in embryo fragmentation, implantation failure or abortion (Agarwal et al., 2008) or impair metabolic activity within embryos for fetal and post-natal development. OS during embryogenesis and in the placenta seems to be implicated in adverse pregnancy outcomes such as birth defects, early pregnancy failure, miscarriage and preeclampsia (Evers et al., 2004; Jauniaux et al., 2006; Agarwal et al., 2005; Forges et al., 2007). Interestingly, NTDs in a mouse model of diabetic embryopathy have been demonstrated to be associated with deficient expression of $\mathrm{Pax} 3$, a gene required for neural tube closure, and hyperglycemia-induced OS was responsible (Li et al., 2005).

\section{Pre-eclampsia and IUGR}

The pathogenesis of pre-eclampsia is established in the first trimester when an inadequate remodeling of the spiral arteries results in a decreased perfusion of the placenta in the third trimester. OS and inflammatory mediators are also involved in the abnormal implantation associated with pre-eclampsia and IUGR. In fact, not only endothelial dysfunction is causally important in the disorder but also alterations in function predate clinically-evident pre-eclampsia, suggesting an interaction of reduced perfusion with maternal factors (Roberts et al., 2003). Abnormal placentation leads in fact to placental ischemia, resulting in generation of placental OS and increased levels of lipid peroxidation (reviewed by Agarwal et al., 2008). HHCY has been implicated in adverse pregnancy outcomes such as placental abruption or infarction and pre-eclampsia (Goddijn-Wessel et al., 1996; Tamura and Picciano, 2006; Braekke et al., 2007). In this context, maternal vitamin $B_{6}$ status was observed to influence reproductive events throughout the entire course of pregnancy (Ronnenberg et al., 2007). The authors reported that this relationship was also found in a case-control study (Wouters et al., 1993) demonstrating significantly lower plasma concentrations of vitamin $B_{6}$ in women with histories of recurrent spontaneous miscarriage compared with control women. Furthermore, significantly lower plasma vitamin $B_{6}$ was detected among women with placental abruption or infarction compared with control women (Goddijn-Wessel et al., 1996). In addition, some studies have documented associations between low vitamin $\mathrm{B}_{6}$ status and inflammatory responses (Friso et al., 200I; Saibeni et al., 2003), and inflammation has been linked to early pregnancy loss (Thellin and Heinen, 2003).

\section{Influence of the preconceptional maternal diet and health status}

Preconceptional maternal nutrition plays a key role in reproductive health (Allaire and Cefalo, 1998). This affects both fertility and the early stages of gestation. Insufficient energy stores may negatively affect ovulation, menses and challenge the beginning of pregnancy. On the other hand, excessive fat stores may inhibit conception by affecting ovulation because of insensitivity to insulin, excess of male sex hormones and overproduction of leptin (The ESHRE Capri Workshop Group). It is also well known that maternal overweight and obesity before conception increase the risk of maternal complications during pregnancy such as gestational hypertension, gestational diabetes, Cesarean delivery, macrosomia, as well as birth defects such as NTDs, other neurological abnormalities, congenital heart disease, intestinal malformations and multiple congenital anomalies (ADA, 2002; Watkins et al., 2003; Bartley et al., 2005; Catalano and Ehrenberg, 2006; Oken, 2009).

Interestingly, the Nurses' Health Study II, a prospective cohort study of more than I 16,000 women aged 24-42 years, demonstrated that a high 'fertility diet' score was characterized by a lower intake of trans fat with a simultaneous greater intake of mono-unsaturated fat, a lower intake of animal protein with greater vegetable protein intake, a higher intake of high-fiber and low glycemic carbohydrates, a greater preference for high fat dairy products and a higher non-heme iron intake (Chavarro et al., 2007a). In particular, the dietary trans unsaturated fats may increase the risk of ovulatory infertility when consumed instead of carbohydrates or unsaturated fats commonly found in non-hydrogenated vegetable oils (Chavarro et al., 2007b) and replacing animal sources of protein with vegetable sources of protein may reduce the risk of infertility because of anovulation (Chavarro et al., 2008). Significantly higher preconceptional dietary intakes of saturated fat was found in Dutch mothers of children with outflow tract defects (OTD), compared with controls (Smedts et al., 2008). In a case-control study, the use of the maternal Western 
diet, e.g. high intakes of organ meat, red meat, processed meat, pizza, legumes, potatoes, French fries, condiments, and mayonnaise but low intakes of fruits, namely low fiber, iron, vitamins, antioxidants and complex carbohydrate intakes and high amounts of saturated fatty acid, protein, sugar and sodium, increased the risk of offspring with a cleft lip or cleft palate approximately 2-fold compared with a Prudent diet, e.g. high intakes of fish, garlic, nuts and vegetables (Vujkovic et al., 2007). These factors are involved in OS and inflammation pathways triggering fertility status. The pathological effects are exerted by various mechanisms including lipid and DNA damage, inhibition of protein synthesis, and depletion of ATP (Agarwal et al., 2005). Nutrients modulate cytokine production by influencing tissue concentrations of the molecules involved in cytokine biology. Aberrant cytokine production is involved in atherosclerosis. The association of dietary fat intake with atherosclerosis has been the subject of extensive studies. In particular, the intake of saturated fat has been suggested to be positively associated with atherosclerosis and coronary heart disease, and sources of saturated fat in the diet mainly derived from animal sources and contain cholesterol. Cholesterol may enhance cytokine production.

Infants of women with pregestational diabetes are reported to have about 3-fold increased incidence of birth defects compared with those of non-diabetic population (Sheffield et al., 2002). Casele and Laifer (1998) have shown that diabetic women frequently enter pregnancy with poor glycemic control.

Some observational studies show an association between short interpregnancy interval and increased risks of adverse outcomes probably due to maternal depletion of nutrients (Smith et al., 2003). As suggested by Smits and Essed (200I), depletion of maternal folate seems to be mainly involved, with particular regard to the risk of fetal growth restriction (van Eijsden et al., 2008).

Another potential problem is that women of reproductive age and pregnant women enter pregnancy without adequate iron reserves or are already iron deficient (Viteri and Berger, 2005; Milman, 2006). Preconceptional anemia, particularly iron-deficiency anemia, was found to be associated with reduced infant growth and increased risk of adverse pregnancy outcomes (Scholl and Hediger, 1994; Ronnenberg et al., 2004; Buckley et al., 2005). Plausibly, it may be supposed that either anemia in the periconceptional period has an independent effect on infant growth by influencing hormone synthesis (Allen, $200 \mathrm{I}$ ) or the moderate preconceptional anemia turns to a more severe anemia during pregnancy (Breymann, 2002) leading to the observed growth deficits. In a prospective observational study in China, it was observed that the risk of preterm delivery and LBW was increased more than 2-fold in moderately anemic women and more than 3 -fold in those with severe anemia during early pregnancy (4-8 weeks) (Zhou et al., 1998).

\section{Effects of periconceptional micronutrients on pregnancy outcomes}

\section{The preconceptional period}

Preconceptional maternal nutritional status and diet impact on reproductive health. Evidence on the preconceptional involvement of micronutrients upon pregnancy outcomes in humans is reported in Table II.
Despite some dietary investigations that refer to periconceptional period, data reflect the maternal nutrition status in the preconceptional period.

Preconceptional folic acid supplementation is a goal of public health to prevent NTDs (reviewed by Pitkin, 2007). A low iron status was suggested to adversely affect important regulators of growth and development in rats (Gambling et al., 2002). A relationship was observed between low ferritin $(<12 \mu \mathrm{g} / \mathrm{I})$, a marker of depleted iron stores, and reduced birthweight, as well as between elevated ferritin $(\geq 60 \mu \mathrm{g} / \mathrm{I})$, a biomarker of acute or chronic inflammation, and increased risk of LBW and fetal growth restriction (Ronnenberg et al., 2004). An open question is whether iron supplementation, which is generally started in the second half of pregnancy, could reduce the rates of preterm LBW, or whether anemia plays a role in placental development solely during early pregnancy and therefore must be prevented prior to conception. Interestingly, prophylactic iron supplementation given from about 12 weeks of gestation to the third trimester among low income women in a randomized controlled trial in North Carolina evidenced that the birthweight was significantly higher in the supplemented groups than in controls (Siega-Riz et al., 2006).

Maternal vitamin $B_{6}$ status was observed to influence reproductive events from the start of pregnancy (Ronnenberg et al., 2007). Conceivably, the effects of poor prepregnancy maternal vitamin $B_{6}$ status on the early gestational events could be explained firstly through the involvement of vitamin $B_{6}$ dependent-co-enzymes in the metabolism of amino acids, lipids, nucleic acids and glycogen. Then, by considering the association between vitamin $B_{6}$ deficiency and impairment of enzymes involved in the structural integrity of arterial walls, it could be supposed to affect implantation and early placental development. Thereby, assessing hematological indices before conception should be of great utility, as they are likely to reflect status in the periconceptional period. On the contrary, biomarker concentrations assessed at various times throughout pregnancy are affected by plasma volume expansion, consequently the interpretation of the relation between these measures and birth outcomes can be challenging (de Weerd et al., 2003a).

Despite the paucity of studies dealing with preconceptional dietary patterns, it is clear that there is a strong relation between imbalance of micronutrients before conception and the successful onset, as well as healthy development of pregnancy as listed below.

\section{Fertility}

Analysis of data from the Nurses' Health Study II evidenced that the consumption of iron supplements and non-heme iron from foods may decrease the risk of ovulatory infertility (Chavarro et al., 2006). Folate seems to be important for oocyte quality and maturation (Ebisch et al., 2007). Zinc plays a role in ovulation and the menstrual cycle. Oocyte maturation, ovulation, luteolysis and follicle atresia are affected by ROS unbalance. OS and apoptosis are involved in folliculogenesis, follicular atresia and luteal regression. In particular, OS leads to detrimental effects on second meiotic division progression, diminished gonadotrophin, antisteroidogenic actions, DNA damage and inhibited protein ATP production (Ruder et al., 2008). For this reason, a positive role of the antioxidant status may be explained by counteracting ROS effects (Forges et al., 2007; Ruder et al., 2008). Similarly, folate, zinc, ROS and thiols affect apoptosis, which is 
Table II Human studies about the impact of preconceptional micronutrients on pregnancy outcomes

\begin{tabular}{|c|c|c|c|c|}
\hline Reference & Type of study & Micronutrient & Outcome & Results \\
\hline $\begin{array}{l}\text { Groenen et al. } \\
\text { (2004) }\end{array}$ & $\begin{array}{l}\text { Case control study. The } \\
\text { Netherlands. Food frequency } \\
\text { questionnaire }\end{array}$ & $\begin{array}{l}\text { Preconceptional intake } \\
\text { of several vitamins and } \\
\text { minerals }\end{array}$ & Spina bifida & $\begin{array}{l}\text { Intakes of iron, magnesium and niacin are } \\
\text { associated with a } 2 \text { - to } 5 \text {-fold increased risk of } \\
\text { spina bifida }\end{array}$ \\
\hline Velie et al. (1999) & $\begin{array}{l}\text { Population-based case- } \\
\text { control. California. A 98-item } \\
\text { food frequency questionnaire }\end{array}$ & $\begin{array}{l}\text { Preconceptional } \\
\text { supplemental and } \\
\text { dietary zinc intake }\end{array}$ & NTDs & $\begin{array}{l}\text { Risk of NTDs in infants and fetuses decreased } \\
\text { with increasing maternal zinc intake }\end{array}$ \\
\hline $\begin{array}{l}\text { Krapels et al. } \\
(2004 a)\end{array}$ & $\begin{array}{l}\text { Case-control study. The } \\
\text { Netherlands. Food frequency } \\
\text { questionnaire }\end{array}$ & $\begin{array}{l}\text { Preconceptional dietary } \\
\text { intake }\end{array}$ & OFC & $\begin{array}{l}\text { Increased intake of iron, magnesium, ascorbic } \\
\text { acid reduced the risk of offspring affected by } \\
\text { OFC }\end{array}$ \\
\hline $\begin{array}{l}\text { Smedts et al. } \\
(2008)\end{array}$ & $\begin{array}{l}\text { Case control study. The } \\
\text { Netherlands. } \\
\text { Semiquantitative food } \\
\text { frequency questionnaire }\end{array}$ & $\begin{array}{l}\text { Dietary intake of } \\
\text { riboflavin and } \\
\text { nicotinamide }\end{array}$ & OTD & $\begin{array}{l}\text { Dietary intakes of riboflavin and nicotinamide } \\
\text { were lower in mothers of a child with an OTD } \\
\text { than in controls }(P<0.05) \text {. Low dietary } \\
\text { intakes of both riboflavin }(<1.20 \mathrm{mg} / \text { day) } \\
\text { and nicotinamide }(<13.5 \mathrm{mg} / \text { day) increased } \\
\text { more than } 2 \text {-fold the risk of a child with an } \\
\text { OTD }\end{array}$ \\
\hline $\begin{array}{l}\text { Verkleij-Hagoort } \\
\text { et al. (2006) }\end{array}$ & $\begin{array}{l}\text { Case control study. The } \\
\text { Netherlands. Food frequency } \\
\text { questionnaire }\end{array}$ & $\begin{array}{l}\text { Dietary intake of } \\
\text { B-vitamins }\end{array}$ & $\begin{array}{l}\text { Congenital hearth defect } \\
\text { (CHD) }\end{array}$ & $\begin{array}{l}\text { A diet low in vitamin } B_{12} \text { is associated with an } \\
\text { increased risk of a child with a CHD }\end{array}$ \\
\hline $\begin{array}{l}\text { Ronnenberg et al. } \\
\text { (2002) }\end{array}$ & $\begin{array}{l}\text { Prospective case-control } \\
\text { study. China. Haematological } \\
\text { assessment }\end{array}$ & $\begin{array}{l}\text { Preconception B } \\
\text { vitamin status }\end{array}$ & $\begin{array}{l}\text { Preterm birth, LBW, } \\
\text { small-for-gestational-age }\end{array}$ & $\begin{array}{l}\text { Risk of preterm birth was } 60 \% \text { lower among } \\
\text { women with vitamin } B_{12} \geq 258 \text { pmol/I than } \\
\text { among vitamin } B_{12} \text {-deficient women } \\
(P<0.05) \text { and was } 50 \% \text { lower among women } \\
\text { with vitamin } B_{6} \geq 30 \mathrm{nmol} / I \text { than among } \\
\text { vitamin } B_{6} \text {-deficient women }\end{array}$ \\
\hline $\begin{array}{l}\text { Ronnenberg et al. } \\
\text { (2007) }\end{array}$ & $\begin{array}{l}\text { Prospective study. China. } \\
\text { Haematological assessment }\end{array}$ & $\begin{array}{l}\text { Preconceptional B } \\
\text { vitamin status }\end{array}$ & $\begin{array}{l}\text { Conception, early pregnancy } \\
\text { loss, clinical pregnancy }\end{array}$ & $\begin{array}{l}\text { Poor vitamin } \mathrm{B}_{6} \text { status decreased the } \\
\text { probability of conception and contributed to } \\
\text { the risk of early pregnancy loss in conceptive } \\
\text { cycles }\end{array}$ \\
\hline
\end{tabular}

important for regulation of follicle atresia (Hussein, 2005), degeneration of the corpus luteum and endometrial shedding. The concentrations of these nutrients may therefore have substantial effects on reproduction. Poor folate status and $\mathrm{HHCY}$ are mainly crucial due to their involvement in cell division (e.g. of oogonia or of granulose cells), inflammatory cytokine production, OS, apoptosis and defective methylation reactions (Forges et al., 2007). In this context, DNA synthesis is important for the development of oocytes, and several enzymes involved in DNA synthesis are zinc- or vitamin B-dependent (Ebisch et al., 2007). Deficiencies of vitamins A, C and D have been demonstrated to result in diminished fertility in rats and rainbow trout as reported by Ebisch et al. (2007). However, though addition of vitamins $C$ and $E$ has been shown to strengthen antioxidant defenses in in vitro media, oral antioxidant supplementation in human studies does not provide definite, conclusive evidence.

\section{Conception and implantation}

The interaction of nutrients with the epigenetic system may lead to variations associated with chromatin remodeling and regulation of gene expression that underlie the developmental programming of pathological consequences in adulthood (reviewed by Junien, 2006). After fertilization, the genome of the zygote undergoes rapid demethylation at coding sequences and at repetitive sequences. After implantation, the embryonic ectoderm and mesoderm genome is hypermethylated, through de novo methylation, whereas the extra-embryonic cell genome, such as the primary endoderm and trophoblast, remains hypomethylated. These processes might be enhanced by methyl donors provided by the folate-methionine pathway. In this context, experiments on mice and rats demonstrated that methyl-supplements and zinc adequate diets during pregnancy affected phenotypic modifications in offspring (Wolff et al., 1998; Cooney et al., 2002; Prasolova et al., 2006; Maret and Sandstead, 2008). Interestingly, Sinclair et al. (2007) provided the first clinical evidence about the extent to which the periconceptional supply of folate, vitamin $B_{12}$ and methionine in mature female sheep affected epigenetic alterations to DNA methylation and adult health-related phenotype in offspring. The methyl-deficient diet around the time of conception resulted in significant changes in the methionine cycles within ovarian follicles of ewes, and led to adult offspring being heavier and fatter, insulin-resistant, eliciting altered immune responses and with elevated blood pressure. These clinical outcomes were associated with modification in methylation status of $4 \%$ of 1400 gene-associated cytidine-guanosine $(\mathrm{CpG})$ islands, mainly in male fetuses, to indicate that periconceptional specific dietary inputs to the methionine cycles may affect a significant part of genome in offspring with long-terms implications for adult health.

The involvement of one-carbon metabolism has been suggested in genetic disorders such NTD. Significantly, the MTHFR genotype has been shown to alter homocysteine metabolism mainly when folate 
status is low, suggesting a genetic-nutrient interactive effect in disease risk (Guéant et al., 2003). Similarly, it has therefore been suggested that gene-nutrient interactions affecting one-carbon metabolism may influence the chance/risk of survival and the risk of trisomy (Wilson et al., 1999). Interestingly, notwithstanding weakly, polymorphisms of folate-related genes are reported to be associated with the prevalence of placental abruption (reviewed by Tamura and Picciano, 2006). Even retinoids represent an example of a gene-nutrient interaction (reviewed by Finnell et al., 2004). This issue raised in 1969 when differential teratogenic responses to retinoids in three rat strains were observed. Then, the large amount of data from several experimental over the past two decades seems to indicate that the biological activity of retinoids is mediated by a retinoid receptor superfamily encoded by different genes and regulating cell proliferation and differentiation (reviewed by Finnell et al., 2004). Namely, the expression of receptors and the availability of retinoid compounds in the adequate concentrations contribute to the normal homeostasis and development of organism. Thereby, alteration in retinoids' concentrations interacting with the embryonic genotype can results in defects such as congenital malformations.

\section{Placentation}

In a prospective study of 1650 pregnancies, low iron status early in pregnant women was found to be inversely related to placental size (Hindmarsh et al., 2000). An inverse relation between serum ferritin concentration and overall measures of peripheral villous capillarization was observed. The surface area of capillaries involved in gas exchange in the mature intermediate and terminal villi was strongly and inversely related to serum ferritin suggesting that anaemia influences the pattern of placental vascularization.

The use of antioxidants seems to be useful to reduce the damage on placenta, thereby the risk of pre-eclampsia because of its limited antioxidant enzyme capacity in the first trimester (Jauniaux et al., 2004). In fact, given that the risk factors for pre-eclampsia are also risk factors for atherosclerosis, other similarities can be suggested (Gratacós, 2000). OS has been hypothesized to be important in altered endothelial function leading to atherosclerosis (Navab et al., 2004). Consequently, it has been assumed that reduced placental perfusion generates free radicals generating systemic oxidative damage, as supported by evidence of OS in the circulation and tissues of women with pre-eclampsia (Roberts et al., 2003). Gratacós et al. (1998) and Jain and Wise (1995) confirmed that serum lipid peroxide levels are significantly higher and serum vitamin E levels significantly lower in women with pre-eclampsia than in women with normal pregnancies. In this regard, the reduction in maternal and placenta antioxidant defense in pre-eclampsia is linked to an excessive depletion of antioxidants through the increased generation of oxygen free radicals (Jauniaux et al., 2006). Moreover, abnormal placentation leads to increased levels of placental lipid peroxidation, probably due to the presence of $\mathrm{NADPH}$ oxidase in the placental syncytial microvillus membrane, producing increased amounts of the superoxide radical (reviewed by Agarwal et al., 2008). At present, nutrition has not been assessed during the periconceptional period or during the early pregnancy in women that later develop pre-eclampsia. However, we may hypothesize that nutrients can affect OS by increasing or decreasing free radicals or antioxidants or by providing substrates for the formation of ROS. Moreover, they could modify inflammatory response in the period when placentation occurs. In particular, adequate intake of vitamin $\mathrm{C}$ and $\mathrm{E}$ during the second trimester of pregnancy is recognized to improve the biochemical incidence of OS (Jauniaux et al., 2006). Similarly, the postulated involvement of deficiencies of trace elements in pre-eclampsia relates to the fact that they are present in metallothionein (zinc), ceruloplasmin (copper), SOD (copper, selenium, zinc) and glutathione peroxides (selenium). In addition, a potential benefit of $\mathrm{n}-3$ fatty acids in preventing pre-eclampsia has been suggested in a prospective cohort study enrolling 1718 women (Oken et al., 2007). Theoretically, n-3 fatty acids may alter prostanoids in favor of vasodilators eicosanoids. Interestingly, lower $\mathrm{n}-3$ fatty acid levels were demonstrated in erythrocytes of women with pre-eclampsia (reviewed by Roberts et al., 2003). Moreover, in an observational study in an Icelandic community with traditional fish and cod liver oil consumption, an inverse association was found between the proportion of long-chain n-3 PUFA in red blood cells of women at the II th to I5th week of pregnancy and placental weight (Magnusardottir et al., 2009).

Some 'placenta events' are postulated to arise from deficiencies of either folate and/or vitamin $B_{12}$ or defects within the methioninehomocysteine metabolic pathways (Goddijin-Wessel et al., 1996; Ray and Laskin, 1999). In this context, HHCY has been shown to provoke vascular inflammation, to decrease the bioavailability of $\mathrm{NO}$ that is an important endothelium vasodilatator, and seems to be associated with the production of ROS (Forges et al., 2007). This means that folate-deficiency or HHCY may underlie endothelian dysfunction, and therefore placental endovasculature (Ray and Laskin, 1999), a theory supported by the observation that elevated serum homocysteine concentrations have been associated with an increased risk of diseases, such as atherosclerotic, thromboembolic and neurodegenerative disorders (reviewed by Diaz-Arrastia, 2000; Kuo et al., 2005; Folstein et al., 2007; Forges et al., 2007).

\section{Embryogenesis}

There is consistent scientific evidence that folic acid (the synthetic form of the vitamin folate) is of critical importance both pre- and periconceptionally in protecting against NTDs in the developing fetus (MRC, 199I; Czeizel and Dudás, 1992; Bendich, 2001; Moore et al., 2003; Czeizel et al., 2004; Shah and Sachdev, 2004; Padmanabhan, 2006). In general, women are advised to take $0.4 \mathrm{mg} /$ day when planning a pregnancy whereas they are recommended to take $4.0 \mathrm{mg} /$ day if they experienced a previous pregnancy affected by NTD (de Bree et al., 1997; Geisel, 2003; Pitkin, 2007). Involved in DNA synthesis and cell division, folic acid plays a vital role in fetal development. Moreover, low folate status seems to increase risk of preterm delivery, LBW and fetal growth restriction as well as other fetal malformations (Czeizel et al., 1999; Tamura and Picciano, 2006). Low $B_{12}$ levels are related to HHCY and high thcy level is associated with NTDs (Mills et al., 1995; Ray and Laskin, 1999; Ray and Blom, 2003) and CHDs (Verkleij-Hagoort et al., 2008). Neural crest cells are involved not only in the embryogenesis of the neural tube, lip and palate, but also in cardiovascular development. The migration and differentiation of neural crest cells is influenced by homocysteine, and vitamin $B_{12}$ is an important determinant in the homocysteine pathway, thereby contributing to the embryogenesis of the heart in the first weeks after 
conception (Verkleij-Hagoort et al., 2008). In a case-control study in the Netherlands, it was observed that the periconceptional intake of thiamine, niacin and pyridoxine (vitamin $B_{6}$ ) seems to contribute to the prevention of orofacial cleft (OFC) defects (Krapels et al., 2004b). This result may be explained by considering vitamin $B_{6}$ involvement into the homocysteine pathway.

Regarding vitamin A, retinoids are thought to be involved in the development of several embryonic systems (reviewed by Finnell et al., 2004). In particular, several embryonic anomalies were observed in vitamin A-deficient quail embryos developing in the absence of RA (Maden et al., 1996). Thus, RA plays a crucial role in central nervous system development (Maiden et al., 1996), i.e. neural crest survival, neuritis outgrowth and hindbrain patterning. Vitamin A and RA are part of the normal regulatory system required. Nevertheless, excessive intake (>10000 IU/day) has been shown to be teratogenic in animals (Williamson, 2006). Malformations were also seen in the human embryo exposed to RA due to treatment of the mother with the acne drug Accutane (13-cis RA) (reviewed by McCaffery et al., 2003). However, other results are contrasting (Dolk et al., 1999). In fact, although the overall recommendation is that vitamin A or retinol intake below $3000 \mu \mathrm{g}(10000 \mathrm{IU}) /$ day is safe, some have argued that vitamin A intake up to $9000 \mu \mathrm{g}(30000 \mathrm{IU}) /$ day represents harmless levels (Miller et al., 1998). In this context, in a population-based case-control study carried out in Norway no evidence of an increased risk of clefting was found with an intake of total vitamin A or retinol of more than $3000 \mu \mathrm{g}$ ( $0000 \mathrm{IU})$ (Johansen et al., 2008).

Animal models have shown that severe maternal zinc deficiency in early pregnancy results in impaired implantation, abortions and fetal malformations, including cleft lip and palate, brain and eye malformations, numerous abnormalities of the heart, lung and urogenital systems (Keen et al., 2003). Biochemical and functional abnormalities can occur as a result of a zinc deficit (Maret and Sandstead, 2008). Interestingly, Keen et al. (2003) reported that even transitory periods of zinc deficiency (5-6 days) can be teratogenic in rodent models, and 3 days of periconceptional zinc deficiency can adversely affect embryonic development. The consideration that zinc deficiency is a teratogenic risk in humans may be supported by the correlation of low plasma zinc concentrations in the first and third trimesters of pregnancy with an increased risk for malformations and LBW, respectively. Zinc deficiency is thought to influence embryonic and fetal development through reduced cell proliferation, or reduced protein synthesis or reductions in rates of tubulin polymerization rather than increased rates of cellular oxidative damage or increased rates of apoptosis and reduced binding of hormones and transcription factors dependent on zinc-finger regions (Jankowski-Hennig et al., 2000; Mackenzie et al., 2002).

A copper deficiency-associated teratogenicity has been suggested (Keen et al., 1998). Embryos obtained from copper-deficient dams and cultured for $48 \mathrm{~h}$ in either copper-adequate or copper-deficient serum displayed numerous abnormalities, such as swollen hindbrains, blisters, blood pooling and distention of the large vessels (Hawk et al., 1998). Since SOD activity was lowest in embryos cultured in copperdeficient serum, and antioxidant (copper-zinc-SOD or GSH peroxidase) supplementation reduced the teratogenicity of the copperdeficient serum, it may be postulated that dysmorphology is due in part to free radical induced damage occurring secondary to an impaired oxidant defense system. Moreover, the copper-deficient embryos also had low cytochrome c oxidase activity compared with control embryos suggesting that multiple factors contribute to copper deficiency-induced abnormalities. Similar results were found in 'Xenopus laevis' embryos from frogs administered a low-Cu diet for 120 day (Fort et al., 2000). On the contrary, although an effect of copper deficiency on the human conceptus has been suggested, no causal relation between low fetal copper concentrations and malformations has been demonstrated. In other words, it has not yet been proven whether the effects of copper deficiency on the embryo or fetus are due directly to a deficiency of the micronutrient, or whether they indirectly occur through the copper deficiencymodulated metabolism of the mother (for example as a consequence of maternal anemia, production of pregnancy hormones or growth factors etc.) (Keen et al., 1998).

In a study aimed to evaluate the effects of ethanol on fetal development, 'Xenopus laevis' embryos were treated with ascorbic acid $2 \mathrm{~h}$ prior to ethanol exposure, and then transferred to medium in the presence or absence of $100 \mathrm{mM}$ ethanol for $12 \mathrm{~h}$. The ethanol-induced ROS production and NF-kB activation were inhibited and the ethanol-treated embryos were protected against microencephaly and growth retardation, suggesting a potential use of ascorbic acid as an effective protective agent for human fetal alcohol syndrome (Peng et al., 2005). Furthermore, antioxidative treatment of streptozotocin-induced diabetic rats with vitamins $E$ and $C$ decreased fetal malformation rate and diminished oxygen radical related tissue damage (Cedeberg et al., 200I). A prophylactic effect of vitamin E against diabetic embryopathy was also demonstrated by Sivan et al. (1996). Inclusion of vitamin $E$ in culture medium, which stimulates development both before and after embryo transfer, was demonstrated to suppress ROS damage in bovine embryos (Olson and Seidel, 2000). On the whole, these data suggest that antioxidants exert beneficial effects on embryo development, possibly by a reduction in the incidence of apoptosis (Agarwal et al., 2008). Similarly, the use of a dietary PUFA that specifically increases arachidonic levels significantly reduced the incidence of diabetic embryopathy in rats (Reece et al., 1996). A significant reduction in the incidence of maternal diabetes-related fetal malformations and IUGR has been reported in diabetic rats also with the supplementation of lipoic acid (Al Gafli et al., 2004).

\section{Conclusions}

The achievement of a successful pregnancy represents one of the fundamental functions of existence. Although scant, data suggest a significant role of micronutrients in the periconceptional period. The nutritional status of women must be a goal for preventing detrimental nutritional unbalances. In particular, diet during the first trimester may be more important to development and differentiation of various organs. Moreover, also preconceptional nutrition is crucial for an optimal onset and development of pregnancy. Unfortunately, nutritional intake of childbearing-age women appears to be inadequate during the preconceptional period (de Weerd et al., 2003b; Mouratidou et al., 2006) mainly in terms of micronutrients, but also considering the global shift towards the Western diet (Popkin and Gordon-Larsen, 2004). Thus, efforts to increase awareness of a healthy diet and lifestyle should be strengthened not only throughout 
pregnancy but also before, given that pregnancies are often unplanned. A meta-analysis evidenced the relationship between preconceptional care and reduced risk of congenital anomalies in the offspring of women with pregestational diabetes mellitus (Ray et al., 200I). Moreover, the role of preconceptional folic acid supplementation in the prevention of NTDs has been documented. In this context, considering the relatively high frequencies of both the MTRR and the MTHFR polymorphisms in the general population, maintenance of adequate vitamin levels (cobalamin and folate) should be stressed for pregnancy (Wilson et al., 1999).

However, conclusive evidence was provided solely for periconceptional folate and prevention of NTDs, and prospective studies related to the association between periconceptional maternal nutrition and pregnancy outcomes are scarce. Interestingly, intakes of magnesium and ascorbic acid above the RDA at 375.9-502.9 and $97.9-295.8 \mathrm{mg} /$ day, respectively, were found to substantially decrease OFC risk (Krapels et al., 2004a). By considering that RDAs for pregnant women are $300-360 \mathrm{mg} /$ day magnesium and $90 \mathrm{mg}$ / day ascorbic acid, these results seem to indicate that the RDAs for these nutrients are insufficient for women of reproductive age. Moreover, although the majority of data indicate that vitamin $A$ intake above $3000 \mu \mathrm{g} /$ day should be avoided in the periconceptional period, this has been recently discussed (Miller et al., 1998; Johansen et al., 2008), and similarly, there is disagreement on the need for iron prophylaxis early in pregnancy.

In particular, causes or at least potential mechanisms between micronutrient status in the periconceptional period and pregnancy outcomes remain still to be well-defined/understood. Specifically, the timing of the potential insults need to be studied in depth both in vitro and in animal models. Moreover, there is a dramatic need for further experimental and interventional human studies, in order to optimize dietary recommendation and thus maternal periconceptional nutritional status.

\section{Funding}

This review was carried out with financial support from the framework of EURRECA (EURopean micronutrient RECommendations Aligned), a Network of Excellence, project no FP6036196-2, funded by the European Commission.

\section{References}

ADA Reports. Position of the American Dietetic Association: nutrition and lifestyle for a healthy pregnancy outcome. J Am Diet Assoc 2002; 102: | 479- 1490.

Agarwal A, Gupta S, Sharma RK. Role of oxidative stress in female reproduction. Reprod Biol Endocrinol 2005;3:28. doi:I0.1186/ 1477-7827-3-28.

Agarwal A, Gupta S, Sekhon L, Shah R. Redox considerations in female reproductive function and assisted reproduction: from molecular mechanisms to health implications. Antioxid Redox Signal 2008; 10:1375-1403.

Akazawa S. Diabetic embryopathy: studies using a rat embryo culture system and an animal model. Cong Anom 2005;45:73-79.

Al Ghafli MHM, Padmanabhan R, Kataya HH, Berg B. Effects of $\alpha$-lipoic acid supplementation on maternal diabetes-induced growth retardation and congenital anomalies in rat foetuses. Mol Cell Biochem 2004;26 I: I 23- I35.

Allaire AD, Cefalo RC. Preconceptional health care model. Eur J Obstet Gynecol Repr Biol 1998; 78:163-168.

Allen LH. Biological mechanisms that might underlie iron's effects on fetal growth and preterm birth. J Nutr 200I; I3 I:58IS-589S.

Allen LH. Multiple micronutrients in pregnancy and lactation: an overview. Am J Clin Nutr 2005;8 I: 1206S-1212S.

Andersen HS, Gambling L, Holtrop G, McArdle HJ. Maternal iron deficiency identifies critical windows for growth and cardiovascular development in the rat postimplantation embryo. I Nutr 2006; 136: I 17I- II77.

Arrigoni O, De Tullio MC. Ascorbic acid: much more than just an antioxidant. Biochim Biophys Acta 2002; 1569:1 -9.

Ashworth CJ, Antipatis C. Micronutrient programming of development throughout gestation. Reproduction 200 I; I 22:527-535.

Bagchi D, Vuchetich PJ, Bagchi M, Tran MX, Krohn RL, Ray SD, Stohs SJ. Protective effects of zinc salts on TPA-induced hepatic and brain lipid peroxidation, glutathione depletion, DNA damage and peritoneal macrophage activation in mice. General Pharmacol 1998;30:43-50.

Bartley KA, Underwood BA, Deckelbaum RJ. A life cycle micronutrient perspective for women's health. Am J Clin Nutr 2005;8 I: I I 88S-I I 935.

Beard J. Iron deficiency alters brain development and functioning. J Nutr 2003; 133: | 468S- | 472S.

Beard J. Recent evidence from human and animal studies regarding iron status and infant development. J Nutr 2007;137:524S-530S.

Beard JL. Why iron deficiency is important in infant development. J Nutr 2008; I 38:2534-2536.

Beard J, Erikson KM, Jones BJ. Neonatal iron deficiency results in irreversible changes in dopamine function in rats. I Nutr 2003; I33: I 174- I I79.

Bendich A. Micronutrients in women's health and immune function. Nutrition 200I;1 7:858-867.

Bhatnagar S, Taneja S. Zinc and cognitive development. Br J Nutr 200I; 85:SI39-SI45.

Black RE. Micronutrients in pregnancy. Br J Nutr 200 I;85:SI93-SI 97.

Bloomfield FH, Oliver MH, Hawkins P, Holloway AC, Campbell M, Gluckman PD, Harding JE, Challis JRG. Periconceptional undernutrition in sheep accelerates maturation of the fetal hypothalamic-pituitary-adrenal axis in late gestation. Endocrinology 2004; 1 45:4278-4285.

Braekke K, Ueland PM, Harsem NK, Karlsen A, Blomhoff R, Staff AC. Homocysteine, cysteine, and related metabolites in maternal and fetal plasma in preeclampsia. Pediatr Res 2007;62:319-324.

Breymann C. Iron supplementation during pregnancy. Fet Mat Med Rev 2002; 13: I-29.

Buckley AJ, Jaquiery AL, Harding JE. Harding Nutritional programming of adult disease. Cell Tissue Res 2005;322:73-79. DOI 10.1007/ s0044I-005-I095-7.

Casele HL, Laifer SA. Factors influencing preconception control of glycemia in diabetic women. Arch Intern Med 1998; I58:1321-1324.

Catalano P, Ehrenberg $\mathrm{H}$. The short- and long-term implications of maternal obesity on the mother and her offspring. BJOG 2006; I 13:1126-1133.

Cedeberg J, Simán CM, Eriksson UJ. Combined treatment with vitamin E and vitamin $C$ decreases oxidative stress and improves fetal outcome in experimental diabetic pregnancy. Pediatr Res 2001;49:755-762.

Cetin I, Alvino G. Intrauterine growth restriction: implications for placental metabolism and transport. A review. Placenta 2009;30:S77-S82.

Cetin I, Alvino G, Radaelli T, Pardi G. Fetal nutrition: A review. Acta Pædiatr 2005;94:7S- I3S. 
Charmel R. Cobalamin (Vitamin $B_{12}$ ). In: Shils ME, Shike M, Ross AC, Caballero B, Cousins RJ (eds). Modern Nutrition in Health and Disease, I0th edn. USA: Lippincott Williams \& Wilkins, 2006, 482-497.

Chavarro JE, Rich-Edwards JW, Rosner BA, Willett WC. Iron intake and risk of ovulatory infertility. Obstet Gynecol 2006; I 08: I |45- I I 52.

Chavarro JE, Rich-Edwards JW, Rosner BA, Willett WC. Diet and lifestyle in the prevention of ovulatory disorder infertility. Obstet Gynecol 2007a; I 1 0:1050- 1058.

Chavarro JE, Rich-Edwards JW, Rosner BA, Willett WC. Dietary fatty acid intakes and the risk of ovulatory infertility. Am J Clin Nutr 2007b; 85:23।-237.

Chavarro JE, Rich-Edwards JW, Rosner BA, Willett WC. Protein intake and ovulatory infertility. Am J Obstet Gynecol 2008;198: 2I0.el-2I0.e7.

Cook JD, Baynes RD, Skikne BS. Iron deficiency and the measurement of iron status. Nutr Res Rev 1992;5: 189-202.

Cooney CA, Dave AA, Wolff GL. Maternal methyl supplements in mice affect epigenetic variation and DNA methylation of offspring. J Nutr 2002; 132:2393S-2400S.

Cordain L, Eaton SB, Sebastian A, Mann N, Lindeberg S, Watkins BA, O'Keefe JH, Brand-Miller J. Origins and evolution of the Western diet: health implications for the 2 Ist century. Am J Clin Nutr 2005; 81:341-354.

Crocker IP, Cooper S, Ong SC, Baker PN. Differences in apoptotic susceptibility of cytotrophoblasts and syncytiotrophoblasts in normal pregnancy to those complicated with preeclampsia and intrauterine growth restriction. Am J Pathol 2003; 162:637-643.

Cross JC, Mickelson L. Nutritional influences on implantation and placental development. Nutr Rev 2006;64:SI2-SI8. doi: 10.1301/nr.may.

Czeizel AE, Dudás I. Prevention of the first occurrence of Neural-Tube Defects by periconceptional vitamin supplementation. N Engl J Med 1992;327: 1832-1835.

Czeizel AE, Tímár L, Sárközi A. Dose-dependent effect of folic acid on the prevention of orofacial clefts. Pediatrics 1999; 104:e66. DOI: 10.1542/ peds. I04.6.e66.

Czeizel AE, Dobó M, Vargha P. Hungarian cohort-controlled trial of periconceptional multivitamin supplementation shows a reduction in certain congenital abnormalities. Birth Def Res (Part A) 2004; 70:853-861.

De Boo H, Harding JE. The development origins of adult disease (Barker) hypothesis. Aust NZ J Obstet Gynaecol 2006;46:4-I4.

de Bree $A$, van Dusseldorp $M$, Brouwer IA, van het Hof $K H$, Steegers-Theunissen RPM. Folate intake in Europe: recommended, actual and desired intake. Eur J Clin Nutr 1997;5 I:643-660.

de Weerd S, Steegers-Theunissen RPM, de Boo TM, Thomas CMG, Steegers EAP. Maternal periconceptional biochemical and hematological parameters, vitamin profiles and pregnancy outcome. Eur J Clin Nutr 2003a;57: I I28- I I34.

de Weerd S, Steegers EAP, Heinen MM, van den Eertwegh S, Vehof RMEJ, Steegers-Theunissen RPM. Preconception nutritional intake and lifestyle factors: first results of an explorative study. Eur J Obstet Gynecol Repr Biol 2003b; I I I:167-172

Díaz JR, de las Cagigas A, Rodríguez R. Micronutrient deficiencies in developing and affluent countries. Eur J Clin Nutr 2003;57:S70-S72.

Diaz-Arrastia R. Homocysteine and neurologic disease. Arch Neurol 2000; 57: $1422-1428$.

Dolk HM, Nau H, Hummler H, Susan M, Barlow SM. Dietary vitamin A and teratogenic risk: European Teratology Society discussion paper. Eur J Obstet Gynecol Repr Biol 1999;83:31-36.

Drewnowski A, Spencer SE. Poverty and obesity. The role of energy density and energy costs. Am J Clin Nutr 2004;79:6-16.
Ebisch IMW, Thomas CMG, Peters WHM, Braat DDM, Steegers-Theunissen RPM. The importance of folate, zinc and antioxidants in the pathogenesis and prevention of subfertility. Hum Reprod Update 2007; 13:163-174.

Edwards LJ, McMillen IC. Impact of maternal undernutrition during the periconceptional period, fetal number, and fetal sex on the development of the hypothalamo-pituitary adrenal axis in sheep during late gestation. Biol Reprod 2002;66:1562-1569.

Evans JL, Goldfine ID, Maddux BA, Grodky GM. Oxidative stress and stress-activated signaling pathways: a unifying hypothesis of Type 2 Diabetes. Endocr Rev 2002;23:599-622.

Evers IM, de Valk HW, Visser GHA. Risk of complications of pregnancy in women with type I diabetes: nationwide prospective study in the Netherlands. Br Med J 2004;328:915-918.

Fang Y-Z, Yang S, We G. Free radicals, antioxidants, and nutrition. Nutrition 2002; 1 8:872-879.

FAO/WHO Report. Folate and folic acid. In: Vitamin and Mineral Requirements in Human Nutrition, 2nd edn. World Health Organization and Food and Agriculture Organization of the United Nations, 2004a, 289-302.

FAO/WHO Report. Iron. In: Vitamin and Mineral Requirements in Human Nutrition, 2nd edn. World Health Organization and Food and Agriculture Organization of the United Nations, 2004b, 246-278.

FAO/WHO Report. Vitamin $\mathrm{B}_{12}$. In: Vitamin and Mineral Requirements in Human Nutrition, 2nd edn. World Health Organization and Food and Agriculture Organization of the United Nations, 2004c, 279-288.

FAO/WHO Report. Zinc. In: Vitamin and Mineral Requirements in Human Nutrition. 2nd edn. World Health Organization and Food and Agriculture Organization of the United Nations, 2004d, 230-245.

Finnell RH, Shaw GM, Lammer EJ, Brandl KL, Carmichael SL, Rosenquist TH. Gene-nutrient interactions: importance of folates and retinoids during early embryogenesis. Toxicol Appl Pharmacol 2004; 198:75-85.

Fleming Tom P, Fleming TP, Kwong WY, Porter R, Ursell E, Fesenko I, Wilkins A, Miller DJ, Watkins AJ, Eckert JJ. The embryo and its future. Biol Reprod 2004;7 I: 1046- 1054.

Folstein M, Liu T, Peter I, Buel J, Arsenault L, Scott T, Qiu WW. The homocysteine hypothesis of depression. Am J Psychiatry 2007; 164:86I-867.

Forges T, Monnier-Barbarino P, Alberto JM, Guéant-Rodriguez RM, Daval JL, Guéant JL. Impact of folate and homocysteine metabolism on human reproductive health. Hum Reprod Update 2007; |-14. doi: I0.1093/humupd/dml063.

Fort DJ, Stover EL, Rogers RL, Copley HF, Morgan LA, Foster ER. Chronic boron or copper deficiency induces limb teratogenesis in Xenopus. Biol Trace Element Res 2000;77:173-187.

Friso S, Jacques PF, Wilson PWF, Rosenberg IH, Selhub J. Low circulating vitamin B6 is associated with elevation of the inflammation marker C-reactive protein independently of plasma homocysteine levels. Circulation 2001;103:2788-279|.

Gagnon R. Placental insufficiency and its consequences. Eur J Obstet Gynecol Repr Biol 2003; I 10:S99-SI07.

Gambling L, Charania Z, Hannah L, Antipatis C, Lea RG, McArdle HJ. Effect of iron deficiency on placental cytokine expression and fetal growth in the pregnant rat. Biol Reprod 2002;66:516-523.

Gardner DS, Pearce S, Dandrea J, Walker R, Ramsay MM, Stephenson T, Symonds ME. Peri-implantation undernutrition programs blunted angiotensin II evoked baroreflex responses in young adult sheep. Hypertension 2004;43:1290- 1296

Geisel J. Folic acid and neural tube defects in pregnancy. A review. J Perinat Neonat Nurs 2003; 17:268-279. 
Gluckman PD, Pinal CS. Maternal-placental-fetal interactions in the endocrine regulation of fetal growth. Role of somatotrophic axes. Endocrine 2002; 19:8I-89.

Gluckman PD, Hanson MA, Cooper C, Thornburg KL. Effect of in utero and early-life conditions on adult health and disease. $N$ Engl J Med 2008;359:6I-73.

Goddijn-Wessel TAW, Wouters MGAJ, vd Molen EF, Spuijbroek MDEH, Steegers-Theunissen RPM, Blom HJ, Boers GHJ, Eskes TKAB. Hyperhomocysteinemia: a risk factor for placental abruption or infarction. Eur J Obstet Gynecol Repr Biol 1996;66:23-29.

Gratacós E. Lipid-mediated endothelial dysfunction: a common factor to preeclampsia and chronic vascular disease. Eur J Obstet Gynecol Repr Biol 2000;92:63-66.

Gratacós E, Casals E, Deulofeu R, Cararach V, Alonso PL, Fortuny A. Lipid peroxide and Vitamin $E$ patterns in women with different types of hypertension in pregnancy. Am J Obstet Gynecol 1998; I 78: 1072- 1076.

Grimble RF. Nutritional modulation of cytokine biology. Nutr 1998; 14:634-640.

Groenen PMW, van Rooij IALM, Peer PGM, Ocké MC, Zielhuis GA, Steegers-Theunissen RPM. Low maternal dietary intakes of iron, magnesium, and niacin are associated with spina bifida in the offspring. J Nutr 2004; 134:1516- I522.

Guéant J-L, Guéant-Rodriguez R-M, Anello G, Bosco P, Brunaud L, Romano C, Ferri R, Romano A, Candito M, Namour B. Genetic determinants of folate and vitamin BI2 metabolism: a common pathway in neural tube defect and down syndrome? Clin Chem Lab Med 2003;4I:I473- I 477.

Gybina AA, Prohaska JR. Increased rat brain cytochrome c correlates with degree of perinatal copper deficiency rather than apoptosis. J Nutr 2003; | 33:336 |-3368.

Gybina AA, Prohaska JR. Variable response of selected cuproproteins in rat choroid plexus and cerebellum following perinatal copper deficiency. Genes Nutr 2006; I:51-60.

Hambidge M. Human zinc deficiency. J Nutr 2000; 130:1344S-1349S.

Hawk SN, Uriu-Hare JY, Daston GP, Jankowski M, Kwik-Uribe C, Rucker RB, Keen CL. Rat embryos cultured under copper-deficient conditions develop abnormally and are characterized by an impaired oxidant defense system. Teratology 1998;57:310-320.

Hindmarsh PC, Geary MPP, Rodeck CH, Jackson MR, Kingdom JCP. Effect of early maternal iron stores on placental weight and structure. Lancet 2000;356:719-723.

Hirschi KK, Keen CL. Nutrition in embryonic and fetal development. Nutrition 2000; 16:495-499.

Homocysteine Lowering Trialists' Collaboration. Lowering blood homocysteine with folic acid based supplements: metaanalysis of randomised trials. BMJ 1998;316:894-898.

Hussein MR. Apoptosis in the ovary: molecular mechanisms. Hum Reprod Update 2005; I I:162-178.

Jain SK, Wise R. Relationship between elevated lipid peroxides, Vitamin E deficiency, and hypertension in preeclampsia. Mol Cell Biochem 1995; I5 I:33-38.

Jankowski-Hennig MA, Clegg MS, Daston GP, Rogers JM, Keen CL. Zinc-deficient rat embryos have increased caspase 3-like activity and apoptosis. Biochem Biophys Res Commun 2000;271:250-256.

Jansson T, Powell TL. Human placental transport in altered fetal growth: does the placenta function as a nutrient sensor? A review. Placenta 2006;27:S9I-S97.

Jauniaux E, Cindrova-Davies T, Johns J, Dunster C, Hempstock J, Kelly FJ, Burton GJ. Distribution and transfer pathways of antioxidant molecules inside the first trimester human gestational sac. J Clin Endocrinol Metab 2004;89: | $452-$ | 458 .
Jauniaux E, Poston L, Burton GJ. Placenta-related diseases of pregnancy: involvement of oxidative stress and implication in human evolution. Hum Reprod Update 2006; I 2:747-755.

Johansen AMW, Lie RT, Wilcox AJ, Andersen LF, Drevon CA. Maternal dietary intake of vitamin $A$ and risk of Orofacial Clefts: a populationbased case-control study in Norway. Am J Epidemiol 2008; 167: | 164-1170.

Joshi R, Adhikari S, Patro BS, Chattopadhyay S, Mukherjee T. Free radical scavenging behavior of folic acid: evidence for possible antioxidant activity. Free Rad Biol Med 2001;30:1390-1399.

Junien C. Impact of diets and nutrients/drugs on early epigenetic programming. J Inherit Metab Dis 2006;29:359-365.

Keen CL, Uriu-Hare JY, Hawk SN, Jankowski MA, Daston GP, Kwik-Uribe CL, Rucker RB. Effect of copper deficiency on prenatal development and pregnancy outcome. Am J Clin Nutr 1998; 67: $10035-1011 S$.

Keen CL, Clegg MS, Hanna LA, Lanoue L, Rogers JM, Daston GP, Oteiza P, Uriu-Adams JY. The plausibility of micronutrient deficiencies being a significant contributing factor to the occurrence of pregnancy complications. J Nutr 2003; 133:1597S-I605S.

King JC, Cousins RJ. Zinc. In: Shils ME, Shike M, Ross AC, Caballero B, Cousins RJ (eds). Modern Nutrition in Health and Disease, I0th edn. USA: Lippincott Williams \& Wilkins, 2006, 27I-285.

Kos M, Vogel M. Morphological findings in infants and placentas of diabetic mother. In: Djelmiš J, Desoje G, Ivanišević M (eds). Diabetology of Pregnancy. Basel: Karger, 2005, 127-|43.

Krapels IPC, van Rooij IALM, Ocké MC, West CE, van der Horst CMAM, Steegers-Theunissen RPM. Maternal nutritional status and the risk for orofacial cleft offspring in humans. J Nutr 2004a; 134:3 I06-31 I3.

Krapels IPC, van Rooij IALM, Ocké MC, van Cleef BAGL, KuijpersJagtman AMM, Steegers-Theunissen RPM. Maternal dietary B vitamin intake, other than folate, and the association with orofacial cleft in the offspring. Eur J Nutr 2004b;43:7- I4.

Kuo H-K, Sorond FA, Chen J-H, Hashmi A, Milberg WP, Lipsitz LA. The role of homocysteine in multisystem age-related problems: a systematic review. J Gerontol Med Sci 2005;60A: I 190-1201.

Kwong WY, Wild AE, Roberts P, Willis AC, Fleming TP. Maternal undernutrition during the preimplantation period of rat development causes blastocyst abnormalities and programming of postnatal hypertension. Development 2000; 1 27:4195-4202.

Ladipo OA. Nutrition in pregnancy: mineral and vitamin supplements. Am J Clin Nutr 2000;72:280S-290S.

Leunda-Casi A, de Hertogh R, Pampfer S. Decreased expression of fibroblast growth factor-4 and associated dysregulation of trophoblast differentiation in mouse blastocysts exposed to high D-glucose in vitro. Diabetologia 200 I;44:1318-1325.

Leunda-Casi A, Genicot G, Donnay I, Pampfer S, de Hertogh R. Increased cell death in mouse blastocysts exposed to high D-glucose in vitro: implication of an antioxidative stress in glucose metabolism. Diabetologia 2002;45:57I-579.

Levine M, Katz A, Padayatty SJ. Vitamin C. In: Shils ME, Shike M, Ross AC, Caballero B, Cousins RJ (eds). Modern Nutrition in Health and Disease, I0th edn. USA: Lippincott Williams \& Wilkins, 2006, 507-524.

Li R, Chase M, Jung S-K, Smith PJS, Loeken MR. Hypoxic stress in diabetic pregnancy contributes to impaired embryo gene expression and defective development by inducing oxidative stress. Am J Physiol Endocrinol Metab 2005;289:E59I-E599.

Locksmith GJ, Duff P. Preventing Neural Tube Defects: the importance of periconceptional folic acid supplements. Obstet Gynecol 1998; 91: $1027-1034$. 
Lyall F. Development of the utero-placental circulation: the role of carbon monoxide and nitric oxide in trophoblast invasion and spiral artery transformation. Microsc Res Tech 2003;60:402-4II.

Mackenzie GG, Zago MP, Keen CL, Oteiza PI. Low intracellular zinc impairs the translocation of activated NF-kB to the nuclei in human neuroblastoma IMR-32 cells. J Biol Chem 2002;277:346I0-346I7.

Mackey AD, Davis SR, Gregory JF III. Vitamin B6. In: Shils ME, Shike M, Ross AC, Caballero B, Cousins RJ (eds). Modern Nutrition in Health and Disease, I0th edn. USA: Lippincott Williams \& Wilkins, 2006, 452-46I.

Maden M, Gale E, Kostetskii I, Zile M. Vitamin A-deficient quail embryos have half a hindbrain and other neural defects. Curr Biol 1996;6:417426.

Magnusardottir AR, Steingrimsdottir L, Thorgeirsdottir $H$, Hauksson A, Skuladottir GV. Red blood cell $n-3$ polyunsaturated fatty acids in first trimester of pregnancy are inversely associated with placental weight. Acta Obstet Gynaecol Scand 2009;88:91-97.

Maret W, Sandstead HH. Possible roles of zinc nutriture in the fetal origins of disease. Exp Gerontol 2008;43:378-381.

McArdle HJ, Ashworth CJ. Micronutrients in fetal growth and development. Br Med Bull 1999;55:499-5I0.

McCaffery PJ, Adams J, Maden M, Rosa-Molinar E. Too much of a good thing: retinoic acid as an endogenous regulator of neural differentiation and exogenous teratogen. Eur J Neurosci 2003; 18:457-472.

McCall KA, Huang C-C, Fierke CA. Function and mechanism of zinc metalloenzymes. J Nutr 2000; 130:1437S-1446S.

Miller RK, Hendrickx AG, Mills JL, Hummler H, Wiegand U-F. Periconceptional vitamin a use: how much is teratogenic? Reprod Toxicol 1998; 1 2:75-88.

Mills JL, McPartlin JM, Kirke PN, Lee JL, Conley MR, Weir DG. Homocysteine metabolism in pregnancies complicated by neural-tube defects. Lancet 1995;345:149-151.

Milman N. Iron and pregnancy - a delicate balance. Ann Hematol 2006; 85:559-565.

Moore LL, Bradlee ML, Singer MR, Rothman KJ, Milunsky A. Folate intake and the risk of neural tube defects: an estimation of dose-response. Epidemiology 2003; 1 4:200-205.

Mouratidou T, Ford F, Prountzou F, Fraser R. Dietary assessment of a population of pregnant women in Sheffield, UK. Br J Nutr 2006; 96:929-935.

MRC Vitamin Study Research Group. Prevention of neural tube defects: results of the Medical Research Council Vitamin Study. Lancet 1991; 338: $131-137$.

Navab M, Ananthramaiah GM, Reddy ST, Van Lenten BJ, Ansell BJ, Fonarow GC, Vahabzadeh K, Hama S, Hough G, Kamranpour N et al. The oxidation hypothesis of atherogenesis: the role of oxidized phospholipids and HDL. J Lipid Res 2004;45:993- 1007.

Newnham JP, Moss TJM, Nitsos I, Sloboda DM, Challis JRG. Nutrition and the early origins of adult disease. Asia Pac J Clin Nutr 2002; I I:S537-S542.

Nicklas TA, Baranowski LNT, Cullen KW, Berenson G. Eating Patterns, dietary quality and obesity. J Am Coll Nutr 200।;20:599-608.

Oken E. Excess gestational weight gain amplifies risks among obese mothers. Epidemiology 2009;20:82-83.

Oken E, Ning Y, Rifas-Shiman SL, Rich-Edwards JW, Olsen SF, Gillman MW. Diet during pregnancy and risk of preeclampsia or gestational hypertension. Ann Epidemiol 2007; 17:663-668.

Olson SE, Seidel GE. Culture of in vitro-produced bovine embryos with vitamin e improves development in vitro and after transfer to recipients. Biol Reprod 2000;62:248-252.
Ornoy A. Embryonic oxidative stress as a mechanism of teratogenesis with special emphasis on diabetic embryopathy. Reprod Toxicol 2007; 24:3I-4I.

Osrin D, de L, Costello AM. Maternal nutrition and fetal growth: practical issues in international health. Semin Neonatol 2000;5:209-219.

Oteiza PI, Olin Kl, Fraga CG, Keen Cl. Zinc deficiency causes oxidative damage to proteins, lipids and DNA in rat testes. J Nutr 1995; 1 25:823-829.

Padmanabhan R. Etiology, pathogenesis and prevention of neural tube defects. Congenit Anom (kyoto) 2006;46:55-67.

Paeratakul S, Ferdinand DP, Champagne CM, Ryan DH, Bray GA. Fast-food consumption among US adults and children: Dietary and nutrient intake profile. J Am Diet Assoc 2003; 103:1332-1338.

Pafilis J, Batistatou A, Iliopoulou A, Tsanou E, Bakogiannis A, Dassopoulos G, Charalabopoulos K. Expression of adhesion molecules during normal pregnancy. Cell Tissue Res 2007;329: I- I I. DOI 10.1007/s0044I-007-0406-6.

Peng Y, Kwok KHH, Yang P-H, Ng SSM, Liu J, Wong OG, He M-L, Kung H-F, Lin MCM. Ascorbic acid inhibits ROS production, NF-kB activation and prevents ethanol-induced growth retardation and microencephaly. Neuropharmacology 2005;48:426-434.

Penland JG, Prohaska JR. Abnormal motor function persists following recovery from perinatal copper deficiency in rats. I Nutr 2004; 134: 1984-1988.

Picciano MF. Pregnancy and lactation: physiological adjustments, nutritional requirements and the role of dietary supplements. I Nutr 2003; 133: 1997S-2002S.

Pitkin RM. Folate and neural tube defects. Am J Clin Nutr 2007; 85:285S-288S.

Popkin BM, Gordon-Larsen P. The nutrition transition: worldwide obesity dynamics and their determinants. Int J Obes Relat Metab Disord 2004; 28:S2-S9.

Prasolova LA, Trut LN, Oskina IN, Gulevich RG, Plyusnina IZ, Vsevolodov EB, Latipov IF. The effect of methyl supplements during pregnancy on the phenotypic modification of offspring agouti coat color in rats. Russ J Genet 2006;42:67-7I. DOI: 10.1134/ SI0227954060I009I.

Prohaska JR. Long-term functional consequences of malnutrition during brain development: copper. Nutr 2000; 16:502-504.

Prohaska JR, Gybina AA. Rat brain iron concentration is lower following perinatal copper deficiency. J Neurochem 2005;93:698-705.

Ravelli ACJ, van der Meulen JHP, Michels RPJ, Osmond C, Barker DJP, Hales CN, Bleker OP. Glucose tolerance in adults after prenatal exposure to famine. Lancet 1998;35 I:173-I77.

Ravelli ACJ, van der Meulen JHP, Osmond C, Barker DJP, Bleker OP. Obesity at the age of $50 \mathrm{y}$ in men and women exposed to famine prenatally. Am J Clin Nutr 1999;70:8II-816.

Ray JG, Blom HJ. Vitamin $B_{12}$ insufficiency and the risk of fetal Neural Tube Defects. Q J Med 2003;96:289-295. doi:10.1093/ qjmed/hcg043.

Ray JG, Laskin CA. Folic acid and Homocyst(e)ine metabolic defects and the risk of placental abruption, pre-eclampsia and spontaneous pregnancy loss: a systematic review. Placenta 1999;20:519-529.

Ray JG, O'Brien TE, Chan WS. Preconception care and the risk of congenital anomalies in the offspring of women with diabetes mellitus: a meta-analysis. Q J Med 200 I;94:435-444.

Reece EA, Wu Y-K, Wiznitzer A, Homko C, Yao J, Borenstein M, Sloskey G. Dietary polyunsaturated fatty acid prevents malformations in offspring of diabetic rats. Am J Obstet Gynecol 1996; 175:818-823.

Rhind SM. Effects of maternal nutrition on fetal and neonatal reproductive development and function. Anim Reprod Sci 2004;82-83:169-181. 
Roberts JM, Balk JL, Bodnar LM, Belizán JM, Bergely E, Martinez A. Nutrient involvement in preeclampsia. J Nutr 2003;133:1684S-1692S.

Ronnenberg AG, Goldman MB, Chen D, Aitken IW, Willett WC, Selhub J, $\mathrm{Xu} \mathrm{X}$. Preconception homocysteine and $\mathrm{B}$ vitamin status and birth outcomes in Chinese women. Am J Clin Nutr 2002;76: I385-I39|.

Ronnenberg AG, Wood RJ, Wang X, Xing H, Chen C, Chen D, Guang W, Huang $\mathrm{A}$, Wang $\mathrm{L}, \mathrm{Xu} \mathrm{X}$. Preconception hemoglobin and ferritin concentrations are associated with pregnancy outcome in a prospective cohort of Chinese women. J Nutr 2004; 134:2586-259I.

Ronnenberg AG, Venners SA, Xu X, Chen C, Wang L, Guang W, Huang A, Wang $X$. Preconception Bvitamin and homocysteine status, conception, and early pregnancy loss. Am J Epidemiol 2007;2-9. DOI: 10.1093/aje/kwm078.

Roseboom TJ, van der Meulen JHP, Osmond C, Barker DJP, Ravelli ACJ, Schroeder-Tanka JM, van Montfrans GA, Michels RPJ, Bleker OP. Coronary heart disease after prenatal exposure to the Dutch famine, 1944-45. Heart 2000;84;:595-598.

Roseboom TJ, van der Meulen JHP, Ravelli ACJ, Osmond C, Barker DJP, Bleker OP. Effects of prenatal exposure to the Dutch famine on adult disease in later life: an overview. Mol Cell Endocrinol 2001;185: 93-98.

Rosemberg $\mathrm{IH}$. Metabolic programming of offspring by vitamin $\mathrm{B} / 2 /$ folate imbalance during pregnancy. Diabetologia 2008;5 I:6-7.

Ross AC. Vitamin A and carotenoids. In: Shils ME, Shike M, Ross AC, Caballero B, Cousins RJ (eds). Modern Nutrition in Health and Disease, I0th edn. USA: Lippincott Williams \& Wilkins, 2006. 35I-375.

Ruder EH, Hartman TJ, Blumberg J, Goldman MB. Oxidative stress and antioxidants: exposure and impact on female fertility. Hum Reprod Update 2008; 14:345-357.

Ryan-Harshman M, Aldoori W. Vitamin $B_{12}$ and health. Can Fam Physician 2008;54:536-54I.

Sacks. Determinants of fetal growth. Current Diabetes Reports 2004; 4:28I-287.

Saibeni S, Cattaneo M, Vecchi M, Zighetti ML, Lecchi A, Lombardi R, Meucci G, Spina L, de Franchis R. Low vitamin $B_{6}$ plasma levels, a risk factor for thrombosis, in inflammatory bowel disease: role of inflammation and correlation with acute phase reactants. Am J Gastroenterol 2003;98:112-117.

Scholl TO. Iron status during pregnancy: setting the stage for mother and infant. Am J Clin Nutr 2005;8 I: 1218S- 1222S.

Scholl TO, Hediger ML. Anemia and iron-deficiency anemia: compilation of data on pregnancy outcome. Am J Clin Nutr 1994;59:492S-50IS.

Scholl TO, Johnson WG. Folic acid: influence on the outcome of pregnancy. Am J Clin Nutr 2000;71:1295S-1303S.

Shah D, Sachdev HPS. Maternal micronutrients and fetal outcome. Indian J Pediatr 2004;71:985-990.

Sheffield JS, Butler-Koster EL, Casey BM, Mclntire DD, Leveno KJ. Maternal Diabetes Mellitus and infant malformations. Obstet Gynecol 2002; 100:925-930.

Sibley CP, Turner MA, Cetin I, Ayuk P, Boyd CAR, D'souza SW, Glazier JD, Greenwood SL, Jansson T, Powell T. Placental phenotypes of intrauterine growth. Pediatr Res 2005;58:827-832.

Siega-Riz AM, Hartzema AG, Turnbull C, Thorp J, McDonald T, Cogswell ME. The effects of prophylactic iron given in prenatal supplements on iron status and birth outcomes: a randomized controlled trial. Br J Nutr 2006;96:929-935.

Sinclair KD, Allegrucci C, Sinh R, Gardner DS, Sebastian S, Bispham J, Thurston A, Huntley Jf, Rees WD, Maloney CA et al. DNA methylation, insulin resistance, and blood pressure in offspring determined by maternal periconceptional $\mathrm{B}$ vitamin and methionine status. PNAS 2007;104:19351-19356.
Sivan E, Reece EA, Wu Y-K, Homko C, Polansky M, Borenstein M. Dietary vitamin $\mathrm{E}$ prophylaxis and diabetic embryopathy: Morphologic and biochemical analysis. Am J Obstet Gynecol 1996;175:793-799.

Smedts HPM, Rakhshandehroo M, Verkleij-Hagoort AC, de Vries JHM, Ottenkamp J, Steegers EAP, Steegers-Theunissen RPM. Maternal intake of fat, riboflavin and nicotinamide and the risk of having offspring with congenital heart defects. Eur J Nutr 2008;47:357-365.

Smith GCS, Pell JP, Dobbie R. Interpregnancy interval and risk of preterm birth and neonatal death: retrospective cohort study. Br Med J 2003; 327:3 I3. doi: I0.1 I36/bmj.327.7410.313.

Smits LJM, Essed GGM. Short interpregnancy intervals and unfavourable pregnancy outcome: role of folate depletion. Lancet 200 I;358:2074-2077.

Sparks JW, Ross JC, Cetin I. Intrauterine growth and nutrition. In: Polin RA, Fox WW (eds). Fetal and Neonatal Physiology, 2nd edn. Philadelphia, USA: WB Saunders Company, 1998, 267-289.

Steegers EAP. Begin at the beginning: some reflections on future periconceptional and obstetric care and research in the Netherlands. Eur Clinics Obstet Gynaecol 2005; I :203-2 I 4. DOI I 0. I007/s I I 296-005-00 I I-8.

Steen MT, Bodie AM, Fisher AJ, MacMahon W, Saxe D, Sullivan KM, Dembure PP, Elsas LJ. Neural-tube defects are associated with low concentrations of cobalamin (Vitamin $\mathrm{B}_{12}$ ) in amniotic fluid. Prenatal Diagn 1998; 18:545-555.

Tamura T, Picciano MF. Folate and hyman reproduction. Am J Clin Nutr 2006;83:993-1016.

Taylor CT. Antioxidants and reactive oxygen species in human fertility. Envirn Toxicol Pharmacol 2001;10:189-198.

The ESHRE Capri Workshop Group. Nutrition and reproduction in women. Hum Reprod Update 2006;12:193-207. doi:10.1093/ humupd/dmk003.No.3.

Thellin O, Heinen E. Pregnancy and the immune system: between tolerance and rejection. Toxicology 2003; 185:179-184.

Traber MG. Vitamin E. In: Shils ME, Shike M, Ross AC, Caballero B, Cousins RJ (eds). Modern Nutrition in Health and Disease, 10th edn. USA: Lippincott Williams \& Wilkins, 2006, 396-4II.

Turnlund JR. Copper. In: Shils ME, Shike M, Ross AC, Caballero B, Cousins RJ (eds). Modern Nutrition in Health and Disease, I0th edn. USA: Lippincott Williams \& Wilkins, 2006, 286-299.

van Eijsden M, Smits LJM, van der Wal MF, Bonsel GJ. Association between short interpregnancy intervals and term birth weight: the role of folate depletion. Am J Clin Nutr 2008;88: I47- 153.

Velie EM, Block G, Shaw GM, Samuels SJ, Schaffer DM, Kulldorff M. Maternal supplemental and dietary zinc intake and the occurrence of Neural Tube Defects in California. Am 」 Epidemiol 1999; I50:605-616.

Verkleij-Hagoort AC, de Vries JHM, Ursem NTC, de Jonge R, Hop WC], Steegers-Theunissen RPM. Dietary intake of B-vitamins in mothers born a child with a congenital heart defect. Eur J Nutr 2006;45:478-486. DOI 10.1007/s00394-006-0622-y.

Verkleij-Hagoort AC, van Driel LMJW, Lindemans J, Isaacs A, Steegers EAP, Helbing WA, Uitterlinden AG, SteegersTheunissen RPM. Genetic and lifestyle factors related to the periconception vitamin $B_{12}$ status and congenital heart defects: a Dutch case-control study. Mol Genet Metab 2008;94: | I2- I 19.

Viteri FE, Berger J. Importance of pre-pregnancy and pregnancy iron status: can long-term weekly preventive iron and folic acid supplementation achieve desirable and safe status? Nutr Rev 2005;63:S65-S76.

Vujkovic M, Ocke MC, van der Spek PJ, Yazdanpanah N, Steegers EA, Steegers-Theunissen RPM. Maternal Western dietary patterns and the risk of developing a cleft lip with or without a cleft palate. Obstet Gynecol 2007; I l 0:378-384.

Watkins ML, Rasmussen SA, Honein MA, Botto LD, Moore CA. Maternal obesity and risk for birth defects. Pediatrics 2003; I I I:I I52- I I58. 
Watkins AJ, Wilkins A, Cunningham C, Perry VH, Seet MJ, Osmond C, Eckert JJ, Torrens C, Cagampang FRA, Cleal J et al. Low protein diet fed exclusively during mouse oocyte maturation leads to behavioural and cardiovascular abnormalities in offspring. J Physiol 2008;586.8:223 I -2244.

West KP Jr, Katz J, Khatry SK, LeClerq SC, Pradhan EK, Shrestha SR, Connor PB, Dali SM, Christian P, Pokhrel RP, Sommer A on behalf of the NNIPS2 Study Group. Double blind, cluster randomised trial of low dose supplementation with vitamin $A$ or $\beta$ carotene on mortality related to pregnancy in Nepal. Br Med J 1999;3 I 8:570-575.

Williamson CS. Nutrition in pregnancy. Nutr Bull 2006;3 I:28-59.

Wilson A, Platt R, Wu Q, Leclerc D, Christensen B, Yang H, Gravel RA, Rozen R. A common variant in methionine synthase reductase combined with low cobalamin (vitamin $B_{12}$ ) increases risk for spina bifida. Mol Genet Metab 1999;67:317-323.

Wolff GL, Kodell RL, Moore SR, Cooney CA. Maternal epigenetics and methyl supplements affect agouti gene expression in $A^{v y} / a$ mice. FASEB J 1998; I 2:949-957.

Wood RJ, Ronnenberg AG. Iron. In: Shils ME, Shike M, Ross AC, Caballero B, Cousins RJ (ed). Modern Nutrition in Health and Disease, I0th edn. USA: Lippincott Williams \& Wilkins, 2006, 248-270.
Wouters MGAJ, Boers GHJ, Blom HJ, Trijbels JMF, Thomas CMG, Borm GFSteegers-Theunissen RPM, Eskes TK. Hyperhomocysteinemia: a risk factor in women with unexplained recurrent early pregnancy loss. Fertil Steril 1993;60:820-825.

Yajnik CS, Deshpande SS, Jackson AA, Refsum H, Rao S, Fisher DJ, Bhat DS, Naik SS, Coyaji KJ, Joglekar CV et al. Vitamin $B_{12}$ and folate concentrations during pregnancy and insulin resistance in the offspring: the Pune Maternal Nutrition Study. Diabetologia 2008; 51:29-38

Young $\mathrm{H}$, Borrel A, Holland D, Salama P. Public nutrition in complex emergencies. Lancet 2004;364: 1899-1909.

Zago MP, Oteiza PI. The antioxidant properties of zinc: interactions with iron and antioxidants. Free Rad Biol Med 200I, 266-274. doi:10.1016/ S089I-5849(0I)00583-4.

Zhou L-M, Yang W-W, Hua JZ, Deng C-Q, Tao X, Stoltzfus RJ. Relation of hemoglobin measured at different times in pregnancy to preterm birth and low birth weight in Shanghai, China. Am J Epidemiol 1998; 148:998-1006.

Submitted on February 10, 2009; resubmitted on April 23, 2009; accepted on May 28, 2009 